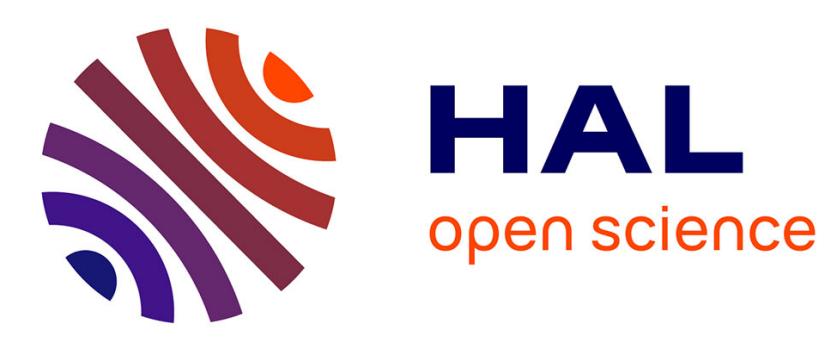

\title{
Socially Responsible Investment in Japan: Its Mechanism and Drivers
}

Céline Louche, Kyoko Sakuma

\section{To cite this version:}

Céline Louche, Kyoko Sakuma. Socially Responsible Investment in Japan: Its Mechanism and Drivers. Business and Professional Ethics Journal, 2008, 82 (2), pp.425-448. 10.1007/s10551-008-9895-9 . hal01098061

\section{HAL Id: hal-01098061 \\ https://hal-audencia.archives-ouvertes.fr/hal-01098061}

Submitted on 22 Dec 2014

HAL is a multi-disciplinary open access archive for the deposit and dissemination of scientific research documents, whether they are published or not. The documents may come from teaching and research institutions in France or abroad, or from public or private research centers.
L'archive ouverte pluridisciplinaire HAL, est destinée au dépôt et à la diffusion de documents scientifiques de niveau recherche, publiés ou non, émanant des établissements d'enseignement et de recherche français ou étrangers, des laboratoires publics ou privés. 


\section{Socially Responsible Investment in Japan: Its mechanism and drivers}

Authors:

\section{Céline Louche}

Vlerick Leuven Gent Management

Kyoko Sakuma

School

Solvay Business School

Reep 1

Centre Emile Bernheim

9000 Gent, Belgium

50, Av. F. D. Roosevelt,

Tel: +32 (0)9 2109798

Brussels, Belgium

Fax: +32 (0)92109890

Tel: +32(0) 7715494

Email: celine.louche@vlerick.be

Email:knsakuma@ulb.ac.be

Key words: socially responsible investment, Japan, contexualization 


\begin{abstract}
The paper explores the emergence and development of socially responsible investment (SRI) in Japan. SRI is a recent field in Japan. It is not clear which model it will follow: the European, American or its own model. Through the analysis of the historical roots of SRI, the key actors and motivations that have contributed to its diffusion, the paper provides explorative grounds to sketch the translation mechanisms of SRI in Japan and offers insight into its future path.

Based on primary and secondary sources of information, the paper shows that although SRI in Japan holds some similarities with the U.S. and especially with the European model, it remains unique. It highlights the importance of translation and reinterpretation in adopting a practice in a new context. SRI in Japan is still in a dynamic construction process. Although we expect it to develop further, it is difficult to depict its future shape and form.
\end{abstract}




\section{Introduction}

SRI is becoming an international phenomenon (Tennant 2007) and has been diffusing amongst Asian countries, first to Australia, Hong Kong, Singapore, then to Japan, and most recently to emerging Asian countries (ASrIA). The Association for Sustainable \& Responsible Investment in Asia (ASrIA) was set up in 2000 in Hong Kong as a non-forprofit, membership association to: "build momentum for SRI in the Asia Pacific region and to raise the standards of SRI practice, through fostering the creation of SRI products and services and through the provision of training and support services" (ASrIA website).

SRI is a new and developing field in Japan. The concept and practice of SRI has been recently transposed into a new and not fully predictable situation. Yet, Japan is a leading SRI nation in Asia outside of Australia, with 34 SRI mutual funds and 4 fund options for pensions with a total market value of 358 billion JPY (approx. 3 billion USD) as of 31 January 2007. ${ }^{1}$ While some reports document the historical and recent development of SRI in Japan (Solomon et al. 2004; ASrIA 2003; Tanimoto 2003; Kawaguchi 2006) as well as its prospects for mainstreaming (Kawaguchi, 2006, Kato, 2006) and its limitations (Solomon et al. 2004; Japan Research Institute 2004, pp. 73-74), very little has been done to analyse why and how SRI developed in Japan.

SRI perceptions and practices obviously vary across different nations and cultures (Sparke 2001). It is not clear which model Japan will follow: the European, the U.S. or its own and unique model. According to Latour (1986), practices need to be adapted to fit new social contexts, which means reinterpretation or translation (Czarniawska and Joerges 1998; Czarniawska and Sevón 1996; Olson et al. 2003). Hence, one may expect SRI in Japan to find its own and specific form.

The purpose of this paper is to understand the emergence and development of SRI in Japan; its specificities in addition to commonalties with European and U.S. SRI practices. It seeks to answer to the following two questions.

- What are the characteristics-actors, vocabulary, strategies and historical roots-- of SRI in Japan?

- What model for SRI in Japan -- US, European or its own?

\footnotetext{
1 The data was provided by Japan Research Institute. The calculation does not include the asset
} under management for pension funds. 1euro $=149$ JPY. See Table 1. 
The paper provides explorative ground to sketch the translation mechanisms of SRI in Japan. It investigates not only the historical roots of SRI in Japan but also the key players and motivations that have helped its proliferation and translation in this new institutional context.

The paper relies both on secondary sources of information, including SRI funds brochures and prospectus, existing surveys and studies, as well as informal discussions with practitioners and finally the authors' observations and experiences.

\section{Japan's context for SRI development}

SRI is perceived and practiced differently in different national socio-economic contexts. As Tessa Tennant, Founding Chair of ASrIA puts it: SRI is understood as screened funds and shareholder action in the US, while more of opportunities for clean energy, water and eco-efficiency in Europe. While some leading funds in Australia have chosen to invest in nuclear activities, in Japan "it is also about CSR nationally with a certain discomfort at looking at the behaviour of Japanese companies globally". ${ }^{2}$ Japanese companies use cultural mechanisms such as philosophy and guiding principles to address CSR without formal administrative processes typical to Western companies (Lewin et al. 1995, p.95). ${ }^{3}$ Yet, their moral obligation is confined within the "community of interest" excluding minorities and foreigners (Wokutch and Shepard 1999).

SRI was imported to Japan and introduced to Japanese companies in the late 1990s when the country was going through a period of "soul-searching" and confidence-building, following a decade of economic recession. This period can be described as confusing and paradoxical (Kim 2004). Four main factors explain this context of confidence-building.

First, largely due to salient pollution after the high-growth era (Solomon et al. 2004), there was a consensus or 'common value' since the 1970s among central and local governments, companies and the population to regulate pollution, an externality of

\footnotetext{
${ }^{2}$ The view was expressed in her article entitled “"'Socially Responsible Investing around the World”, Special 15th Anniversary Issue Summer 2007, GreenMoneyJournal.com.

${ }^{3}$ Nippon Keidanren adopted the Charter for Good Corporate Behavior in 1991. Solomon et al. (2004) and Kim (2004) argue that it sought to discipline the corporate sector with ethics and compliance through several revisions of the Charter in 1990s.
} 
companies (Machii). In the late 1980s and 1990s, a wave of strengthened environmental standards were arriving from Europe especially with regard to the extended producer responsibility, recycling and take-back measures embodied in the EU's WEEE and RoHS directives. Influenced by EU developments, the Japanese Ministry of Environment requested companies to publish environmental reports in 1997, which later resulted in a burgeoning number of environmental reports as well as ISO14001 certifications (Solomon et al. 2004). Despite of their belief in good environmental track records (Keizai Doyukai 2004), Japanese companies are under more and more pressure not only from the EU but also more recently from Chinese legislation.

Second, Japan's economic success, built on the Japanese corporate governance model, lost its foundation in the economic doldrums of the 1990s. Japanese companies were criticized both from within and outside of Japan for its model of balancing the interests of various stakeholders including wider society (Kim 2004). Amid debates on a new model of Japanese governance throughout 1990s (Sakuma 2001), the Japanese government revised the Commercial Code in 2002 to allow an Anglo-Saxon way of management control through the committee system (auditing, remuneration and appointment) combined with an independent board of directors. ${ }^{4}$ However, an overwhelming majority of companies retain the traditional model of "internalism" governance (Buchanan 2007) and shy away from external control (Gilson and Milhaupt 2004). ${ }^{5}$

Third, scandals started to become a daily feature of corporate Japan, despite widely-held views that Japanese companies are social institutions delivering philanthropic contributions, life-long employment and seniority (Kim 2004). Unlike previous cases associated with corporate racketeers, recent scandals have involved unethical behaviour at large and renowned companies: legal infringement of health \& safety standards and falsifying accounts and reporting. This led to a public outcry that Japan was not excluded from corporate scandal cases such as Enron and Worldcom (Inukai 2005; Solomon et al. 2004). Despite Nippon Keidanren's (Japan Business Federation) efforts to upgrade the

${ }^{4}$ Between 2001 and 2004, commercial codes were revised 6 times, mainly to strengthen the function of internal auditors.

${ }^{5}$ Keidanren, Japan's largest industry association recently claimed that flexibility in governance systems, such as setting up only one of the three committees, is needed to suit individual companies' specificities. http://www.keidanren.or.jp/japanese/policy/2006/040.html 
Charter for Good Corporate Behaviour (1991) throughout the 1990s (Solomon et al. 2004; Kim 2004), corporate ethics scandals still show little sign of subsiding.

Forth, Japanese companies have sought to secure home-based stable ownership in light of increasing foreign ownership. The share ownership by foreign institutions reached $18.3 \%$ (4.7\% in 1990) in monetary terms in 2001 , and $28 \%$ in 2006 , while individual investors also emerged as a significant ownership group (18\%). ${ }^{6}$ Secured control cemented through cross-shareholding among affiliated financial institutions and companies faltered, which resulted in one in four listed companies seeking to attract individual investors. They introduced non-taxable gifts (cf. dividends), so-called "Kabunushi Yutai". Kabunushi Yutai are for example company products, discounted transportation tickets, gift certificates, etc, independent of dividend payout. Individual Japanese investors are perceived as being loyal, whereas foreign owners are perceived as deceitful since they sell stocks in mass when business results are disappointing (Nomura Research Institute 2006). ${ }^{7}$

Within this social and economic context, SRI from Europe and the US was introduced.

\section{Roots of SRI}

Early steps. The widely held opinion, considers that SRI emerged in Japan in the late 1990s with eco-funds. Eco-funds are mutual funds which invest exclusively or predominantly in companies which are actively working to improve the environment or have otherwise environmentally friendly business operations (OECD 2001; ASrIA 2003; Ministry of Environment Japan 2004; Japan Research Institute 2004; Kabeya 2004; Matsuno and Goriki 2006; Kato 2006). ${ }^{8}$ The first eco-fund was introduced by Nikko Asset Management in partnership with Good Bankers, in August 1999. Within the 6 following months, 4 other eco funds were launched. As noted by Eiichi Takeda from Nikko Asset

${ }^{6}$ The Tokyo Stock Exchange data.

7 The triangle merger, which allows foreign companies to acquire a Japanese company via a Japanregistered subsidiary as effective from July 2007, is likely to magnify Japanese companies' urge to stay Japanese.

${ }^{8}$ Supporters of the other view claim that an embryonic form of SRI appeared earlier, in the 1980s in the form of shareholder activism triggered by a nuclear plant accident (Tanimoto, 2003). However, it was more a single incident, as shareholder activism on ESG issues did not take root afterwards. 
Management in an interview in 2003, investment funds such as mutual funds or pension funds are quite recent in Japan: "Japanese prefer the bank deposit to the investment" claims Eiichi Takeda ${ }^{9}$. The first Japanese eco-fund emerged in a timely manner for mutual funds investment in 1999-2000 as well as in an increasing awareness of the Japanese public on environmental issues (Tanimoto 2003; Kabeya 2004). In this context, eco-funds have been imported from the West and introduced into the market as new financial products.

Beginning 2000. The introduction of eco-funds has been very successful. Assets under management (AUM) of Nikko eco-fund reached 23 billion JPY within only two weeks of its inception ${ }^{10}$, and by March 2000 the eco-funds market grew to 220.7 billion JPY. ${ }^{11}$ The Bank of Japan's zero-interest rate policy (February 1999 till August 2000) also gave fund marketers an opportunity to tell bank depositors to switch to better financial and environmental return-generating investments. Most of the participants were first time investors, primarily made up of women and young people. However, the IT bubble burst in mid-2000 and the consequent IT stock plunge reversed this trend in growth. Despite a growing number of eco funds from 1 to 9 in 4 years and the introduction of the first SRI fund [Asahi Life SRI Social Action Fund], the total AUM diminished to 71.8 billion JPY in September 2003 (Sompo Japan calculation). No new SRI or eco-fund was launched in 2002. As a result, lots of attention was given to the way in which SRI funds selected companies in the West and Japan as debated at the ASrIA Tokyo conference in 2002.

2003. Around 2003, SRI started to gain recognition in Japan. In 2003 the first SRI fund for pensions was launched (July) by the Sumitomo Trust Bank, ${ }^{12}$ and in the same month Morningstar Japan launched the first Japan-specific SRI index called MS-SRI. Moreover, the Pension Fund Association of Japan issued the Proxy Voting Principle. This

\footnotetext{
${ }^{9}$ Interview by William Baue in "Attitudes and Actions Behind the Growth of SRI in Japan", Socialfunds.com, June 20, 2003

${ }^{10}$ A comment of Ms. Tsukushi, President of Good Bankers in Economic Research Institute for Northeast Asia (ERINA) report vol. 45, 2002.

${ }^{11}$ Sompo Japan calculation, in the presentation on 20 November 2003 in Tokyo.

12 Two pension funds belonging to KDDI and Shinsei Bank mandated Sumitomo Trust Bank to manage 25 billion JPY through the SRI fund (Solomon et al. 2004).
} 
series of initiatives were rather a counter proposal to Western SRI criteria and the massive arrival of SRI questionnaires from overseas. Japanese companies felt strongly that some of the Western SRI criteria were not relevant to Japanese companies (ASrIA 2003, p.1). According to them, SRI overseas assumptions and criteria addressed the wrong problems in Japanese society (ASriA 2003; Solomon et al. 2004; Sakuma 2004). There was a common feeling that no country should attempt to inflict its ethical beliefs on another (Wong 1991; Bowie 2004). The Japan Association of Corporate Executives in fact issued a White Paper on CSR to highlight "Japan's way of CSR". However, individual companies exposed to cross-border business had a pragmatic reaction - both pride for Japan's practice, and interest in international standards for CSR. Western SRI questionnaires have nevertheless had a significant impact on the growth of domestically designed SRI funds and Japan-relevant CSR criteria and methodologies.

Today. The initial expansion has been followed by the introduction of a second SRI index, the FTSE4Good index for Japan in September 2004. As a result, the financial community as well as investors started to more concretely grasp the concept of SRI, which had for a long time remained very vague. With the launch of the UN Principles for Responsible Investment in June 2006, the Japanese financial community has begun to understand the international scope of SRI, and began to benchmark its own CSR activities against the leading Western financial institutions. Due to this international catch-up zeal, the Japanese financial community and consultants have shifted their focus on legal and non-legal means to push the volume of SRI from previous concerns on the Western criteria fitness to Japan's context.

As of 31 January 2007, the number of SRI funds increased to 34, representing 358 billion JPY of AUM (see annex 1).

\section{The SRI community}

Four key actors can be identified in the Japanese SRI field, namely SRI research organisations, SIF Japan, financial institutions and stock listed companies. SRI research organisations together with companies have played a determining role in developing and diffusing SRI in Japan, however both groups with different motives. Japanese companies have tried to regain trust by actively engaging in CSR activities, both at the national and international level. 


\section{SRI Research organisations}

SRI Rating Organisations as well national Social Investment Forums have flourished in a number of countries. Today all financial institutions managing an SRI fund, in Europe, the U.S. or Japan use the services of at least one SRI rating organisation and a SRI fund that does not use the services of such an organisation may be perceived as unreliable (Louche 2004; Gond and Louche 2005). SRI rating organisations are today recognised as the professional body, the 'experts' on SRI. This seems to be the case in Europe, the U.S. as well as in Japan.

In total there are 15 SRI research organisations active in Japan, which is a lot compared to Europe and the U.S. and shows how fast SRI has developed in this country. Similar to Europe and the U.S., there are two main forms of SRI rating organisations in Japan: independent SRI research organisations, domestic and foreign, and affiliated SRI research organisations. Affiliated SRI research organisations are different from in-house SRI research: they are think tanks dealing with multiple themes and are affiliated with financial groups (see annex 2 for more detailed information).

The group of domestic independent SRI rating organisations consists of three organisations: Good Bankers, IntegreX and Morningstar/CPRD. Good Bankers, established in 1998 by a former Japan-based employee of a European bank, was the first Japanese SRI rating organisation. Good Bankers played an important role not only in linking ecology with mutual fund products, but also in encouraging Japanese financial institutions to rethink their business model and be more innovative. In its mission statement in Japanese it states:

"...we have reached the conclusion that the financial sector, through the provision of financial products and services should contribute to societal progress and development, should be able to go out of the present impasse and explore new clients and markets. ....Good Bankers will introduce the concept 'SRI' as a new product line and will provide and plan diverse products and services that will match the changing financial market in the post-Big Bang era". ${ }^{13}$

Good Bankers clearly positions SRI as a commercial activity for mainstream financial institutions rather than a niche and norm-based product limited to a certain type

\footnotetext{
13 Translated literally by the authors from Japanese into English. The mission statement on Good
} Bankers' English webpage did not carry the Japanese equivalent as of October 2007. 
of bank or institution. It also promotes SRI as a way/tool to get the financial market out of a long recession period. In April 2006, Good Bankers launched a new business with Mitsubishi UFJ Research \& Consulting to help the Tokyo Stock Exchange, Inc. design tailor-made SRI indexes.

The second independent SRI rating organisation, IntegreX, was set up in 2001, three years after Good Bankers, by a former trader in an international and Japanese brokerage house. From the start, IntegreX introduced a different message from Good Bankers -the revival of Japanese management rather than aiding financial institutions out of an impasse. It stresses that the integrity and sincerity of managers is the core of good management in Japan and due to this the need for a Japan-specific SRI approach. The President of IntegreX claimed on its website:

" ..... it is important to develop SRI that is suitable to Japanese society and culture in order to build safer, fairer and better Japan. ....If we succeed in creating a mechanism by which the integrity of corporate management is translated into market competitiveness, it will benefit not only companies' improved brand image, but also adds values to stakeholders..." ".

In one of her recent books, she wrote:

"SRI, which was started in the US, as a means of embodying Christian belief, will be reborn in Japan as a means to support the fundamental corporate goals, namely, economic efficiency, competitiveness and sustained growth. Japanese companies are able to regain a success model of "Japanese management" (Akiyama and Hishiyama 2004). ${ }^{14}$

The third independent SRI research provider is the Centre for Public Resource Development (CPRD), a non-profit organisation established in 2000 by individuals with $\mathrm{NGO}$, government and academic backgrounds. CRPD's aim was distinct from the previous two SRI research companies in the way that it sided with stakeholders. It aimed to strengthen the non-profit sector and establish new social systems by developing public resources through partnerships and collaborations. CPRD provides screening results to Morningstar Socially Responsible Investment Index (MS-SRI). However, Morningstar maintains rights over final constituent selection based on the CPRD recommendation and the development of derived products such as the MS-SRI research tool, an on-line application service to extract company data and research reports. ${ }^{15}$

\footnotetext{
${ }^{14}$ Translated by the authors from Japanese to English.

${ }^{15}$ Morningstar mentions about the division of labour on its dedicated website.
} http://www.morningstar.co.jp/sri/pdf/sri_rulebook_100.pdf 
Although the three organisations, Good Bankers, IntegreX and Morningstar/CPRD, have different approaches, they all position SRI as a commercial project. This perspective is comparable with the development of SRI in Europe (Louche 2004) but differs from the U.S. approach of SRI which has its roots and still is linked to activism. CPRD's original goal of becoming a catalyst for new social systems, a kind of a soft version of U.S. activism, was soon transformed into a commercial project of Morningstar Japan. Good Bankers and IntegreX have contributed in the construction of a business model similar to financial rating agencies promoting economic efficiency, competitiveness and sustainable growth. Such an approach is consistent with the way they present SRI, a financial product for mainstream financial institutions. In Europe and more specifically France, Arese, a SRI rating organisation which has now merged with Vigeo, played a rather similar role (Gond 2005).

The group of affiliated SRI research organisations consists of four providers and can be described as think tanks that have an affiliation with a large financial group. The constitution of those conglomerates dates back to the pre-war period. The Japan Research Institute (JRI) is affiliated with the Sumitomo Mitsui Financial Group, Sompo Japan Research Institute with the Sompo Japan Group and Mitsuibishi UFJ Research \& Consulting with the Mitsubishi UFJ Financial Group (Annex 2). Although the degree of affiliation is almost intangible today, group-affiliated financial institutions almost always appoint their group-affiliated research institute for their SRI funds screening. All SRI funds by Sumitomo Trust \& Banking and Sumitomo Trust \& Banking (STB) Asset Management are researched by JRI., two funds of Sompo Japan Asset management are screened by Sompo Japan Research Institute together with Sompo Japan Risk Management, and two of three SRI funds managed by Mitsubishi UFJ Asset Management are researched by Mitsubishi UFJ Research \& Consulting ${ }^{16}$. Another common feature for the affiliated research institutes is that they provide a variety of research and consulting within and outside the group affiliations, with SRI representing just a fraction of emerging business revenues(between $0.05 \%$ to $1.5 \%$ of their total revenue). ${ }^{17}$

The last group, the foreign independent SRI rating organisations, have a limited role to date despite their large presence in Japan's SRI (8 out of 15 research companies

\footnotetext{
${ }^{16}$ Mitsubishi UFJ Asset Management using Good Bankers for Family Friendly fund is the exception.

${ }^{17}$ SIF Japan study, September 2005.
} 
active are of non-Japanese origin). Only two of the foreign SRI research companies active in Japan ${ }^{18}$ are voting members of ASrIA. ${ }^{19}$ Non-Japanese SRI rating organisations have difficulties to penetrate the Japanese market as it often requires forming a 'trustworthy' or 'exclusive' partnership with local financial institution. No financial institution uses the same foreign research provider. It seems that foreign SRI research organisations are first and foremost used as a communication tool to signal their SRI orientation in the eyes of the media and public. However, we expect the role of foreign SRI research organisations to change, as they are becoming more strategic in expanding their client base in Japan, possibly with Japanese language-based services. Such a move is already observed for example with Innovest which opened its own office with Japanese staff in 2006 in Tokyo or IRRC which acquired its base in Tokyo as a result of a merger with ISS in 2005 (Today RiskMetrics Group, as a result of ISS's acquisition in January 2007).

\section{-------Insert Table 1------}

\section{Japanese SIF}

As in many European countries and the U.S., Japan has its own 'SIF', Social Investment Forum. SIF Japan was officially set up in November 2003 and has its origins in a study group formed by companies, NGOs, academics active in the GRI Forum Japan (renamed to Sustainability Forum Japan as of 1 August 2007), some CSR consultants and individuals promoting SRI/CSR in Japan. It is a non-for-profit membership association. Unlike SIF U.S. and Eurosif, SIF-Japan was not a financial sector initiative. As of April 2008, four out of 15 board members represent the financial sector: Daiwa Securities Co., Lehman Brothers Securities, Sumitomo Trust and Banking and the Development Bank of Japan, a government-financed bank. The rest of the board is represented by various stakeholders $^{20}$.

The lack of interest from the financial community may be explained by a competition factor. Indeed, several practitioners active in Japan's SRI argue that once

\footnotetext{
${ }^{18}$ Stock at Stake was also founding member until its merger with Vigeo Group.

19 The third voting member active in SRI research in Japan is Good Bankers.

${ }^{20}$ The other stakeholder members of the SIF Japan board are: three CSR related NGOs, two
} academics, one company, one securities company-related research institute (Daiwa), two consulting companies specialising in CSR and one SRI independent research organisation (IntegreX) and one affiliated research organisation (JRI) . 
one's competitor is in one organisation, it does not want to join that organisation. While Daiwa Securities are in, Nomura Securities has no interest, and while IntegreX and other SRI leading persons are in, Good Bankers has no interest, for example. In addition, SIFJapan's secretary-general is the same person as Sustainability Forum Japan's secretarygeneral. Co-founder of CPRD is affiliated with the Sustainability Forum Japan through its auditor role. Another noteworthy point is that SIF-Japan is not a voting or associate member of ASrIA, while the Korean Sustainable Investment Forum (KoSIF) is an associate member. SIF Japan seems to struggle not only to reach the status of a 'pivotal platform' domestically, but also international recognition, without ASrIA membership.

Our observations and numerous discussions with actors in the SRI Japanese field lead to the conclusion that the Japanese SIF remains an unfocused organisation with a rather ambiguous role. As of today, it is difficult to predict whether it will become an important actor in the field or stay marginal.

\section{Financial institutions and SRI funds}

Financial institutions have been a passive group of actors in Japan's SRI arena. As of January 2007, there are 34 SRI funds in Japan and all 34 are mutual funds (see Annex 1). Ten of the funds are eco-funds that focus on environmental screenings, two are themefunds that focus on the empowerment of women in the workplace, and the remaining twenty-two funds are SRI funds that screen on environment, social, compliance/governance criteria.

Affiliation with ASrIA seems to be an important anchor for some financial institutions. Daiwa Securities, Sompo Japan Risk Management and Sumitomo Trust \& Banking are voting members of ASrIA. Interestingly, Nikko Cordial Co. with whom Good Bankers launched Japan's first SRI (eco) fund is not a voting member of ASrIA. Yet the company was the most frequent sponsor amongst Japanese institutions during the threeyear (2002-2004) period. Daiwa Securities, a voting member, sponsored in 2002 and 2004, while the others show no record of active sponsorship for events and projects. ASrIA plays an importance role as a platform for SRI research companies and financial institutions, which seek legitimacy of their activities in Japan.

\section{Companies}


Japanese companies, as the object of evaluation and the recipients of SRI questionnaires, played an important role in Japan's SRI development in two ways: mobilising the CSR debate and enhancing disclosure. The companies' CSR drive was in a sense triggered by the media. Since 2003, the media coverage of CSR skyrocketed (Daiwa Investor Relations 2006) ${ }^{21}$ becoming the prime driver for CSR by early 2005. Internal reforms to combat scandals were not a driver of CSR for a majority of companies, according to the Keidanren survey in $2005 .^{22}$

As the guardians of the Japanese management system, Japanese companies responded to mounting SRI inquiries on ISO14001 certification by increasing the number of certified sites by 390\% between August 1999 and the end 2003 (Tanimoto 2003, p.243). By the end of January 2006 Japan was ranked the No.1, with 18.8\% $(19,477)$ of the total environmentally certified sites $(103,583)$ in the world (Peglau P., German Environmental Agency).

Moreover, Japanese companies are stepping up their CSR disclosure. Japanese companies comprise more than $20 \%$ of the total reports that use the Global Reporting Initiative (GRI) guidelines, making Japanese companies top amongst the global GRI reporters (KPMG International Global Sustainability Services 2005). CSR reports are not confined to large companies: $23 \%$ of Japanese companies (51\% amongst large companies) prepared a separate report covering both the environment and society, and $32 \%$ had a CSR department or a CSR committee in 2003 (Keizai Doyukai 2004). During the period 20042005, amongst the CSR/environmental reports published by Japanese companies, the percentage of those citing their SRI index inclusion increased from $7.6 \%$ to $10.6 \%$. (General Press Corporation 2005, p.26).

${ }^{21}$ The media coverage of CSR issues increased by 17 times from 225 in 2002 to 4,311 in 2006, while the coverage on investor relations (IR) remained between 400 and 500.

${ }^{22}$ The prime reasons for companies to take up CSR were popularity in the media $(66.7 \%)$, CSRconscious activities in economic associations such as Keidanren (56.7\%) and SRI questionnaires (39.3\%), while internal reform to combat scandals $(13.3 \%)$ and benchmarking $(10.7 \%)$ were found in a minority of companies. Keidanren surveyed 1,324 member companies during the period March -April 2005 (response rate: $43 \%$ ). http://www.keidanren.or.jp/japanese/policy/2005/066.pdf 


\section{Definitions and Vocabulary}

Definitions and vocabulary are important indicators of the national 'identity' of SRI. Although we can find some similarities with Europe and the U.S., there are also interesting and unique features within the Japanese SRI field.

\section{Definitions}

Most SRI funds refer to the Eurosif definition: 'to combine investors' financial objectives with their concerns about social, environmental, ethical (SEE) and governance (G) issues. Yet, despite the text-book definition widely employed, the narrative explanation of SRI in Japan places a different emphasis in comparison to Europe. It places importance on "investment method" or "investment activities" rather than investors' objectives (see Annex 3)

Moreover, the word "ethical investment" has never been translated into Japanese as the use of "ethics" is regarded in Japan as reserved for groups of intellectuals or those who have had a Christian education..

Furthermore, SRI is defined as a mixture of the U.S. and European approach. It takes the U.S. scope of screening, shareholder activism and community investment, in addition to the European understanding of shareholder activism -engagement.

\section{Vocabulary}

Japanese SRI uses a softer language when compared to the European and U.S. SRI community. Wording such as eco-, earth-, employee- and family-friendly, and social contribution are used. Imported words such as CSR, compliance and engagement are used without Japanese language equivalents. Like many traditional mutual funds, some (12 out of 30) SRI funds have a nickname that highlights their stock-picking criteria: ecological beauty (12 out of 30), bright future or human relationship (5 out of 30) (Table 1).

There are roughly three sets of vocabulary in the Japanese SRI scene: eco-efficiency/ecofriendly, compliance/integrity, and 'CSR' ${ }^{23}$ Eco-efficiency, which has been promoted by the World Business Council for Sustainable Development, is a variation of the business case for CSR, in which improvements in the handling of environmental matters results in efficiencies in the manufacturing process, and hence in competitiveness and profit (Louche

\footnotetext{
${ }^{23}$ Recent emergence of women-related funds was not taken into account, because of their minority
} values in today's SRI scene. 
and Lydenberg 2006, p.18). This concept, the most important underlying value associated with SRI in Japan, has been popularised not only by Good Bankers but other followers.

The notion of compliance in Japan includes both legal and ethical aspects. This notion emerged onto the scene in reaction to a call for honesty and integrity amongst top managers amid scandals. Honesty and integrity was popularised by IntegreX and its method of screening, R-BEC001. However, with the increasing media coverage of scandals, the accent has somewhat shifted to post-scandal management capability from a 'good heart' that could prevent non-compliance and scandals. Keidanren's 2004 revision of the Charter for Good Corporate Behaviour states that legal compliance is the core of social responsibility. And the recent survey of Keidanren ${ }^{24}$ confirms this thinking. ${ }^{25}$

CSR, without any translation is an increasingly popular expression amongst SRI funds in Japan. It encompasses a variety of notions including a management system of integrity and social contribution, Shakai Koken in Japanese. A management system of integrity means demonstrating a good environmental and human resources performance, reflecting the recent discussion around ISO26000. Whereas Shakai Koken is the concept closely associated with charities, community involvement and corporate citizenship. The concept became known through Keidanren's launch of the 1\% Club in November 1990, which was modelled on the US practice of percentage clubs. ${ }^{26}$ In fact, the first SRI (eco) fund, an unspecified fraction of Nikko Ecofund's return, was annually donated to the greening activities of NGOs and communities during October 2000 and December 2006. Some other SRI funds also give part of their return to charities.

\section{Approaches to SRI}

Despite the textbook definition of SRI adopted in Japan, Japanese SRI is predominantly screening. No engagement is acknowledged amongst Japan's SRI

${ }^{24}$ Keidanren surveyed 1,324 member companies during the period March-April 2005 (response rate: $43 \%$ ). http://www.keidanren.or.jp/japanese/policy/2005/066.pdf

${ }^{25}$ Legal compliance and administrative guidance compliance are the most important CSR issues today $(96.6 \%)$ and in the future (73.6\%), followed by safety and quality $(64.7 \%$ and $43.9 \%)$, environment $(66.3 \%$ and $60.5 \%)$, privacy protection and information security (61\% and $39.3 \%)$ and risk management $(42.5 \%$ and $56.8 \%)$.

${ }^{26}$ As of September 2006, the $1 \%$ Club was composed of 271 companies and 1,026 individuals which voluntarily contribute $1 \%$ of their profit to the social activities. 
practitioners, while community investment is still in the process of identifying Japan's distinctive features in contrast to U.S. definitions and practices.

\section{Screening}

Within the Japanese context, and like Europe and the U.S., screening is usually understood as selecting companies based on evaluations on social, environmental and/or ethical and governance issues simultaneously or BEFORE the financial analysis (Tanimoto, 2003). However three SRI funds conduct non-financial screening AFTER the selection based on financial and stock performance data. ${ }^{27}$

Exclusionary criteria, that is the rejection of companies due to their involvement in certain activities -the most widely used criteria in the U.S. and Europe being alcohol, tobacco, gambling and weapons - are employed by two global index tracking SRI funds screened by foreign SRI research organisations: Nikko Global Sustainability Fund screened by SAM based on DJGSI and Nomura Global SRI 100 screened by FTSE and based on the FTSE4Good Global 100. Foreign SRI research firms providing domestic equity screening services use positive screening exclusively. It is important to note, however that some SRI funds, including Tokyo Teachers' Mutual Aid Association (TTMAA) excludes companies with a past record of causing scandals stemming from nonlegal compliance (Tanimoto, 2003, p.92). Morningstar SRI Japan Index also replaces companies associated with non-compliance scandals with those possessing a clean record.

With respect to screening criteria, there is a tendency to focus more on crisis management skills such as post-scandal transparent communication and execution of management turn-over, rather than a more in-depth screening of issues that cause such scandals. One reason for this tendency is the absence of reliable information sources. All domestic SRI research organisations rely predominantly on questionnaires, CSR reports and other disclosed company information (SIF-Japan 2005). NGO or civil society sources have not gained an equal or trustworthy status comparative to the major news media. This makes it difficult for information users to defend their final ratings or assessments. Secondly, budget and time constraints. Most domestic SRI research organisations use a data package that allows semi-automatic production of rating results. The number of

\footnotetext{
${ }^{27}$ They are Nikko Eco Fund, DIAM's Eco Fund, and Sumitomo Mitsui Asset Management's Eco
} Balance Fund. 
companies per analyst per year vary from 37.5 (Interrisk) to 283 (IntegreX) ${ }^{28}$, reflecting various styles of research (Annex 2). One practitioner in Japan mentions that the SRI analyst is not yet an established profession and that it is difficult to find them.

The screening criteria specific to Japan are of legal and administrative compliance. These types of indicators typically focus on Japan-based or non-consolidated entities' human resources practices, which is another dissimilarity from European and U.S. screening criteria, which focus more on consolidated performances.

These criteria are found mostly in the human resources area where there has not been much enforcement. ${ }^{29}$ One example is the percentage of disabled workers in the workforce and measures to extend senior employees' (those reaching the retirement age of 60 ) employment contracts. The former indicator's benchmark is $1.8 \%$, a legally required rate for companies with more than 56 employees, yet the average rate for the companies in 2004 was 1.46\%. Amongst Tokyo-based companies (20\% of Japan's corporate establishments), it was $1.44 \%$ in 2006 . The latter indicator refers to the legal provision that requires companies to either (1) extend the retirement age, (2) introduce a continual reemployment system, or (3) abolish the retirement age (effective April 2006). The law moreover encourages companies to make other efforts to promote the employment of seniors.

\section{Engagement / shareholder activism}

Proxy voting has a recent history in Japan, however neither U.S. or European styles of shareholder activism have been seen as of September 2007. Yet, in a relatively voting shy country, 1998 was an 'epoch-making year' for proxy voting history in Japan (Yoji Yoshioka, CEO of Japan Proxy Governance Ltd.). The Pension Fund Association of Japan (PFA) published a first study on the corporate governance of pension funds, followed by the launch of the Principles of Corporate Governance by the Corporate Governance Forum of Japan. This was followed by the insurance of corporate governance principles targeted at Japanese companies by the California Public Employees' Retirement System (CalPERS ).

${ }^{28}$ Calculating the part-time staff as 0.5 full-time, divided by the number of companies researched per year.

${ }^{29}$ Companies failing to achieve the required rate have been allowed to compensate by paying 50,000 JPY per missing disabled person per month. 
In February 2003, after a series of guidelines the Pension Fund Association (PFA) unveiled the PFA Proxy Voting Principle, because it needed to encourage Japanese pension funds to vote (Yano, 2004, Yoshitaka, 2006) in light of rising foreign ownership. The PFA Principle successfully created a wave of shareholder responsibility to not endorse proposals blindly and do cast a vote (Yano, 2004; Yoshioka, 2006).

A recent study by Jacoby (2007) documents evidence of limitations of US-style shareholder activism in Japan due to persistent cultural obstacles. Jacoby (2007) investigated CalPERS' involvement in Japan. He showed that over the last 15 years CalPERS has shifted its initial solo activism, to local partnerships and finally to companylevel 'relational investing'. RIETI (2003) also points out that proposals submitted by individual shareholders are considered odd and are almost never supported by the institutional investors.

\section{Community Investing}

Unlike Europe, community investing is considered more and more as an integral part of SRI in Japan. SIF Japan's regular media monitoring includes initiatives by local banks in raising funds for specific local issues. These types of activities are somewhat different from U.S. community investing, which focuses mainly on support for small, community-development banks, credit unions, and revolving loan funds. In addition, SRI investors focus on the community lending records of larger banks, looking for evidence that they lend to economically disadvantaged neighbourhoods and regions. The Japan Research Institute, introduced a new definition of SRI as 'a provider of finance by way of investment or loans' in its 2004 report submitted to the Ministry of Trade, Economy and Industry (METI). (Table 2).

-Insert Table 2

The report identifies the Community Reinvestment Act in the U.S. and Community Investment Tax Credit in the UK as vehicles to convert community investing into a local welfare policy. This broadened scope of SRI is reflected in the new METI project entitled “2007 Environmental Community Business Project” (METI 2007). ${ }^{30}$ This one-year subsidy aims to promote a business model in which small and medium size companies collaborate with local NGOs and communities in environmental sustainability in reaction

\footnotetext{
${ }^{30}$ Calls for projects were opened until 2 April 2007 and the selected projects will be announced on 1
} June 2007. METI's project is available at http://www.meti.go.jp/policy/eco_business/ 
to the fact that companies are reluctant to form partnership with NGOs.; despite the dramatic increase of incorporated NGOs (non-profit organisations or NPO in Japanese) after the enactment of the Law to Promote Specified Non-profit Activities (NPO Act) in 1998.

\section{Similarities and differences with Europe and the U.S.}

From the above analysis, we can conclude that SRI in Japan holds a number of similarities especially with Europe. The main characteristics of SRI in Japan are summarised in Table 3 and Annex 4.

SRI is a recent phenomenon in Japan -beginning in the late 1990s with no links to religion, unlike the U.S. and Europe. SRI in Japan was launched with a clear desire to create a market mechanism to channel household financial assets into SRI and the corporate sector. But Japan had been confronted by SRI earlier through the questionnaires sent by overseas SRI research organisations. This even resulted in questionnaire fatigue amongst companies in the 2000s - before SRI really took off in Japan - particularly since they had the feeling that the questions were not adapted to their national context and therefore at times irrelevant.

Japan's actors, vocabulary and strategies have a number of common characteristics with Europe, which is not surprising since Europe has been regarded as a model for the development of SRI in Japan.

Three actors have played an important role in the emergence and development of SRI in Japan: companies, SRI rating organisations and the government. All three have had different motives for stimulating SRI in Japan. Japanese companies felt challenged by foreign investors and have been confronted with the importance of showing sound signs of corporate social responsibly in order to remain legitimate. Therefore a number of them have actively engaged in developing CSR strategies and have been active in involving the financial community to increase their own credibility. Indeed companies as well as the government perceive CSR as a threat to the one of their prides, namely the Japanese management system. From this point of view, it has become crucial for them not only to perform as well as other countries, but even better; therefore companies have embraced certifications such as the ISO and others. SRI rating organisations, and especially the independent organisations, have played an important role in rationalising SRI and building a business model for SRI. The government has stimulated SRI by signalling its interest in 
the development of the SRI industry. The government also sees SRI as a way to rebuild national confidence.

Overall, Japan has adopted a 'soft' version of European SRI, choosing for engagement rather than activism, and for positive screening rather than exclusion. This approach reflects the conflict-avoidance nature of Japanese society. The focus of SRI in Japan is not on bringing broad social changes, as some may describe the U.S. approach, but rather in stressing the financial and commercial benefits for both investors and companies. The preference for soft and conflict-free language, coupled with its origin as a new financial product, implies that aggressive or activist connotations of screening activities have not taken root in Japan. Moreover, NGOs and the civil sector (SIF-Japan, 2006) and consumer movements (Wokutch 1990) are relatively underdeveloped in Japan, which makes it difficult for SRI to address societal challenges from the point of view of the affected stakeholders of companies.

From the analysis of the emergence and development of SRI, the very determinant for Japan's SRI future seems not to be the interests of holders of "stakes" 31 but rather an institutional design to foster recognition of the Japanese management system.

SRI in Japan is also unique because of the criteria SRI funds use. There are some divergences in terms of criteria between Japan, Europe and the U.S. As Siggelkow (1999) argued, investment fund managers (agent) should undertake decision-making on behalf of their investors (principle). This means that U.S. and European fund managers are accountable to U.S. and European investors, and Japanese SRI fund managers are accountable to Japanese investors. But one may argue that if both Western investors and Japanese investors focus on the real stakes faced by Japanese companies in local stakeholder relations, then screening criteria and indicators are likely to converge. This would mean that Western investors should adapt their criteria to the local reality. But this remains an open debate. In either case, if a perception gap between investors and fund managers can be mitigated through a more reliable and transparent analysis on the real state of companies' behaviour, it could help citizens in both regions to make more

${ }^{31}$ One positive note is that the SRI community, partly influenced by UK legislation protecting whistle-blowers, played a part in legalising a whistle-blowing procedure. Thanks to this legislation, a formerly untouchable collusive practice amongst a dozen construction and building companies (Kyoryu affair) was scrutinised, and unpaid overtime salaries of 167,958 workers was unveiled by the Labor Standards Inspection Offices, resulting in 23.295 billion JPY premium payment imposed on 1,524 firms. 
responsible choices as consumers and investors (Tencati et al. 2004). Such a test case will be whether the recent high-profile legal and administrative non-compliance incidents, such as the anti-trust violation in the construction sector and the failure to pay claims in the nonlife insurance sector, will become an integral part of sector-specific sustainability analysis. $^{32}$

Table 3

\section{Discussion: What model for SRI in Japan?}

SRI in Europe and the U.S. is on its way to becoming mainstream (Louche and Lydenberg 2006). Although it has not yet arrived, there is strong evidence that mainstream financial analysts and fund managers individually recognize the importance of environmental, social and governance (ESG) dimensions (Ambachtsheer 2005; Taylor Nelson Sofres 2003; Pleon 2005). Moreover, there are emerging initiatives such as the Enhanced Analytics Initiative and Yachnin \& Associates (2006), which promote the integration of this type of information into standard company valuation models.

In Japan, while some commitments towards mainstreaming have been observed, it is debatable if SRI will ever embrace mainstreaming in the future. Fund managers recently interviewed by the Financial Times acknowledged that "much of the money flowing into SRI investments remains very short-term". ${ }^{33}$

A recent survey by Daiwa Investment Relations (January 2006) shows that $30 \%$ of asset managers and financial analysts think that SRI screening influences investment decision-making. Another survey by Mitsubishi UFJ Asset Management (MUAM) on Japanese pension funds reveals that trustees are reticent to implement SRI strategies because of fiduciary duty and concerns about the financial performance of SRI funds (Kato

32 The collusive behaviours in Japan's construction sector was a taboo topic even among Japanese SRI research circles until the recent steel bridge bid-rigging case involving 47 companies, which resulted in the arrest of high-ranking officials at Japan Highway Public Corporation and company officials in July 2005. The Supreme Court ordered a total of 640 billion JPY penalties to 23 companies on 10 November 2006. Likewise, insurance companies' failure to pay claims was a non-issue for the SRI funds despite increasing complaints by consumers until an administrative action was taken against all 26 non-life insurance companies by the Financial Services Agency in November 2005.

${ }^{33}$ Financial Times article, "Japan's ethical funding makes breakthrough”, 3 July 2006. 
2006). While over $60 \%$ of pension funds are interested in SRI, about $12 \%$ are actually willing to implement SRI and over $70 \%$ respond neither Yes or No. Moreover, over $80 \%$ of pension funds think that financial performance is a prerequisite for SRI, and $65 \%$ think that the financial performance is the most important selection criteria for SRI funds.

Yet, mainstreaming might be advancing invisibly. ${ }^{34}$ Despite a tendency towards risk aversion, Japanese mainstream investors have shown some commitments: several SRI options for pension funds were launched by September 2006 and eight financial institutions signed up to the United Nations' Principles for Responsible Investment in one year. ${ }^{35}$. Moreover, several developments suggest that Japan might follow the European pattern of mainstreaming, meaning a take up by mainstream investors fostered by government initiatives:

- The government is interested in redesigning an economic system in which private companies including financial institutions are given a role in channelling household savings into SRI funds and community investment. According to Toyoda (2006), if the increasing number of SRI mutual funds does not reach a comparable volume to the US and Europe, it becomes a natural and logical step for the government to forge an architecture driving a part of the financial assets of the highlyenvironmentally conscious Japanese people to SRI. The Japan Research Institute (2004) proposes a policy menu, in which SRI can be fully deployed in order to replace part of the role and functions played by the government sector in relation to companies.

- A growing awareness of fiduciary duty amongst pensions and asset mangers since the burst of the economic bubble (Nitta, 2002) was heightened by a move by MUAM, the largest pension mandate holder in Japan, to implement SRI into its pension management in June 2006. MUAM has recently contracted a legal expert to provide a fresh interpretation of fiduciary duty in the Japanese context (Kato

\footnotetext{
${ }^{34}$ In an interview with Socialfunds.com, June 20, 2003, Mr. Hayami, fund manager responsible for Asunohane SRI fund stated "In my scenario, mainstream investors will move toward SRI, though this movement may be invisible from the outside. I think that in Japan, SRI development will continue without the SRI name".

${ }^{35}$ Signatories are Daiwa Asset Management, Sumitomo Trust \& Banking, Mitsubishi UFJ Asset Management, Mitsui Asset Trust \& Banking、Mizuho Trust \& Banking, Nissay Asset Management, Sompo Japan, Kikkoman Pension Fund.
} 
2006). Findings of this report are in line with the Freshfields Bruckhaus Deringer report (2005).

- The Pension Fund Association announced its first proxy voting guideline in 1999. PFA emphasizes voting as an important means for enhancing shareholder value, and is thus considered as a means to meet fiduciary duty. In the same year, 7 financial institutions adopted their own proxy voting principle.

- Stock exchanges are encouraging SRI. The Tokyo Stock Exchange announced in March 2006 that it would start a customised SRI index, in collaboration with two domestic SRI research companies, Good Bankers and Mitsubishi UFJ Research \& Consulting. From the previous experience of the MS-SRI Index, FTSE4Good index and other indexes, it might help popularise and legitimise SRI. In 2005, $10.6 \%$ of the companies publishing environmental/sustainability reports sited their SRI index inclusion in environment/CSR reports, up from 7.6\% in 2004. (General Press Corporation 2005, p.26).

- An increasing number of government initiatives are designed to promote SRI. ${ }^{36}$ The Ministry of Environment (MOE) is seeking to formulate a tax policy by which institutional investors are incentivised to integrate environmental criteria into their investments, according to a report by the Study Group on Financial Institutions' environmental strategies (2005). The Ministry of Finance (MOF) on the other hand promotes SRI as a financial institution CSR initiative, and is studying the possibility of introducing statutory SRI by public pension funds (Ministry of Finance, July 2006). Finally, the Cabinet Office recently commissioned a study on how to shift the individual financial assets of senior citizens, which accounts for $60 \%$ of 1,500 trillion JPY (approximately 10 trillion euro), into SRI and social activities that could substitute public money. The survey results reveal that $41.9 \%$ of people in their 50s and 60s are ready to invest in SRI if it meets their conditions, and nearly $80 \%$ want to know in which types of activities their financial assets are invested (Nomura Research Institute 2006).

${ }^{36}$ Besides the initiative, the Law promoting activities that considers environmental matters was enacted in April 2005, by which the Japanese nationals shall endeavour to gather environmental information to use in their investment and other activities (Article 5). 
Japan is not an exception when it comes to SRI. Although it started relatively late compared to other countries--twenty years later than in the US and ten years later than in some European countries-- SRI is gaining ground within the Japanese financial community. Japan is joining the 'SRI worldwide movement'. As has been documented in several studies, SRI is diffusing across numerous countries ((Boxenbaum and Gond 2005; Louche 2004; Louche et al. 2005; SiRi company 2005).

In Europe, as in the US, the growth of SRI has been driven by a desire to redefine the relationship between companies and society and find mechanisms to exercise a quasiregulatory power over companies without direct governmental interventions (Louche and Lydenberg 2006). Drivers in Japan have been of a quite different nature. The 6-year long growth of Japanese SRI has been driven by two main factors: first, a desire to create a market mechanism to channel household financial assets into SRI and the corporate sector; and second, a desire to legitimize the Japanese management system through new sets of vocabulary such as eco-efficiency, ethics compliance, management integrity and social contribution in the eyes of the Japanese public and the world.

\section{Conclusion and further research}

SRI in Japan remains a unique case. Although it has imported a global concept, it has managed to adapt it to its specific national context. SRI in Japan does have some similarities with SRI in the U.S. and in Europe, but it shows numerous characteristics that are quite unique. SRI is going through a translation process which requires adaptation. This process is not yet over. The SRI field in Japan is still in a very dynamic construction process where changes are taking place at a very rapid pace. Therefore, as of today it is difficult to depict the future shape and form of SRI in Japan. But it is there and we expect it to stay.

Our finding has some practical implications for global SRI investors looking to invest in Japanese companies. The fact that the different drivers underpinning the Japan's SRI construction means that SRI investors need to consider the context in which Japanese companies operate in their evaluation and investment decisions. Contexulization might be able to reduce a gap between the perceived sustainability of companies and real state of companies. In this light, a new research is on the way to shed light on the role of contextualization in the SRI decision-making process. The paper also suggests two other 
areas of further research to enhance the understanding of the mechanism of translation in Japan's SRI field. First, an evolving relationship between the SRI rating and asset management companies needs to be examined due to the fact that the mainstreaming of SRI might have progressed beneath the surface in Japan. SRI Mainstreaming was accompanied by the in-housing of research in Europe. Such research will unveil the evolution of SRI inquiries in Japan's SRI scene and might support or contradict our initial finding. Second, the emergence and development of community investing in the Japanese context warrants further investigation. It is quite possible that the local grassroots movements amongst local cooperatives and NGOs who support the rights and well-being of disfavoured populations existed prior to the 'official birthday' of SRI in Japan.

\section{Acknowledgement}

We wish to thank Steven Lydenberg of Domini Social Investments, Kanji Tanimoto of Hitotsubashi University, and Toshihiko Fujii of Research Institute of Economy, Trade and Industry for their valuable comments to our draft version of the paper. We also acknowledge the useful suggestions by Nigel Roome of Solvay Business School in structuring the paper. Furthermore, we thank many SRI actors in Japan for sharing their ideas and giving us valuable insights into their actual thinking. Especially, we are very grateful for SIF Japan and Japan Research Institute for providing us the key SRI data used for this paper. However, only the authors are responsible for all interpretations and conclusions as well as for all remaining errors and omissions. 


\section{References}

Akiyama O. (2003), What is Socially Responsible Investment? - How to foster good companies, Productivity Publisher.

Akiyama O. and T. Hishiyama (2004), Basic Knowledge about Socially Responsible Investment -companies with high integrity will grow, Iwanami Active Shinsho.

Ambachtsheer, J. (2005), SRI: What do investment managers think? Mercer Investment Consulting.

Annual Economic Report, July 1999, Economic Planning Agency.

Aoki M. (1994), "The Contingent Governance of Teams: Analysis of Institutional Complementarity", International Economic Review, Vol. 35, No. 3 (Aug., 1994), pp. 657-676.

Aoki M. (1995), "Controlling the Insider Control" in ed. by M. Aoki and H. Kim, Corporate Governance in Transitional Economies: Insider Control and The Role of Banks, EDI Developmental Studies, Washington: World Bank.

Aoki M. and M. Okuno (1997), Comparative Institutional Analysis (Keizai Sisutemu no Hikaku Seido Bunseki), Tokyo University Press.

Association for Sustainable \& Responsible Investment in Asia (ASrIA), "Foreign Versus

Local: The Debate about SRI priorities in Japan”, October 2003.

ASrIA annual conference 2002, "Asian Values and SRI ", a workshop, Tokyo, 28-30 October 2002.

Benson K. L., T. J. Brailsford, and J. E. Humphrey (2006), “Do Socially Responsible Fund Managers Really Invest Differently?”, Journal of Business Ethics 2006 65: pp. 337-357.

Bowie, N. E. (2004), "Relativism and the Moral Obligations of Multinational Corporations", in Ethical Theory and Business, eds. Beauchamp, T. L. and N. E. Bowie, 7th edition.

Boxenbaum, E., and Gond, J.-P. (2005), Importing 'Socially Responsible Investment' in France and Quebec: work of contextualisation across varieties of capitalism. Forthcoming.

CSR Archive, a portal managed by Japan Research Institute.

Czarniawska, B., and Sevón, G. (1996), Translating organizational change (Barbara Czarniawska and Guje Sevón ed.). New York: Walter de Gruyter.

Czarniawska, B., and Joerges, B. (1998), Winds of organizational change: how ideas translate into objects and actions, Organizing organizations, Nils Brunsson

Dewenter, K.L. (2003), “The risk-sharing role of Japanese keiretsu business groups: evidence from restructuring in the 1990s", Japan and the World Economy Volume 15, Issue 3 , August 2003, Pages 261-274 
Daiwa Investor Relations, "2006: the year of IR - Livedoor, Enron, continued disclosure and scandals, increasing interests in CSR (in Japanese)", 22 December 2006.

Eurosif, The 2006 European SRI Study

Eurosif, Socially Responsible Investment among European Institutional Investors, 2003 Report.

Freshfields Bruckhaus Deringer, A legal framework for the integration ofenvironmental, social and governance issues into institutional investment, October 2005.

General Insurance Association of Japan, statistics on complaints 1999-2003, August 2004.

General Press Corporation, "Environmental Report/CSR report Analysis 2005" (in Japanese)

Gilson R.J. and C. J. Milhaupt (2004), "Choice as Regulatory Reform: The Case of Japanese Corporate Governance”, http://www.isnie.org/ISNIE04/Papers/milhaupt.pdf.

Gribben C. and A. Faruk (2004), "Will UK pension funds become more responsible? A survey of trustees", January, Just Pension.

Hirota S. and K. Ikeo (1996), "Corporate Finance and Managerial Efficiency", in H. Itoh ed., The Japanese Firm as a System, Tokyo, University of Tokyo Press.

Inukai S. (2005), “Turning towards International CSR standards - strategies and actions of Japanese companies" (in Japanese), a presentation presented at Giving Korea 2005 conference, Korea, 26 October 2005.

Jacoby S. M. (2007), "Principles and Agents: CalPERS and corporate governance in Japan”, Journal compilation with 2007 Blackwell Publishing Ltd., Volume 15 Number 1, January.

Japan Automobile Recycling Promotion Centre, "About the environmental initiatives of securities companies" (in Japanese), document 6 by the Fund Management Group, September 2006.

Japan Research Institute (2004), “A research report examining CSR and new money flow"(in Japanese), a report prepared for the Ministry of Trade, Economy and Industry and Research Institute of Economy, Trade and Industry (RIETI), March 2004. 
Jin H. H., O.S. Mitchell, J. Piggott (2005), "Socially Responsible Investment in Japanese pensions", National Bureau of Economic Research working paper 11747, November.

Johan P. Olsen ed. Middleton, WI: Global Management, LLC, Book Service.

Kabeya H. (2004), "The present stage of SRI” (in Japanese), Daiwa Review, no. 14, 2004, pp.106- 119.

Kato M. (2006), "Direction of SRI from now on" (in Japanese), on-line report Shiten, Mitsubishi UFJ Asset Management, June 2006.

Kawaguchi M. (2005), “A new revolution in SRI - Materiality and Transparency” (in Japanese), Management Strategy Research, Daiwa Research Institute, 29 September 2005.

Kawaguchi M. (2006), “The latest SRI development - soon to take off?” (in Japanese), Management Strategy Research, Daiwa Research Institute, 29 August 2006.

Kawamura M. (2002), "How Socially Responsible Investment (SRI) Could Redefine Corporate Excellence in the $21^{\text {st }}$ Century", NLI Research Institute 2002, No. 160.

Keizai Doyukai, "'Evolution of Market" and socially responsible management -towards building trust for corporations and sustained value creation" (in Japanese), March 2003.

Keizai Doyukai, "Corporate Social Responsibility in Japan: Current status and Future Challenges, CSR Survey 2003”, January 2004.

Kim K.B. (2004), "Finding an entry point for the promotion of corporate social responsibility in small and medium- sized enterprises in Japan", Preliminary draft. At http://www.jil.go.jp/english/reports/visiting.html.

Lewin A. Y., T. Sakano, C. U. Stephens and B. Victor (1995), “Corporate citizenship in Japan: Survey results from Japanese firms", Journal of Business Ethics, Volume 14, Number 2 / February.

Louche, C. 2004. Ethical Investment: processes and mechanisms of institutionalisation in the Netherlands, 1990-2002, PhD dissertation, Erasmus University Rotterdam: Available at: https://ep.eur.nl/retrieve/3259/ESM-dissertation-3003.pdf. Rotterdam: Optima Grafische Communicatie. 
Louche, C., Gond, J.-P., and Ventresca, M. (2005), Legitimating social rating organisations: on the role of objects in the micro-processes of SRI legitimacybuilding in Europe. Paper presented at the IABS, Sonoma, California.

Louche, C., and Lydenberg, S. (2006), Socially responsible investment: difference between Europe and United States. Vlerick Leuven Gent Management School Working Papers.

Machii K., "Research on Environmental policy-making process in Japan, Korea and China (Nichi-Kan-Chu no Kankyoseisaku no Keisei Katei ni Kansuru Kenkyu), Social $\begin{array}{llllllllll}\text { Analysis Research Cluster I } & 0 & 4 & \text { V } & M & 0 & 1\end{array}$ http://www.soci.ous.ac.jp/gs/study/files/i04vm01.pdf.

Matsuno H. and C. Goriki (2006), "The Role of CSR theory and its future direction” (in Japanese) in ed. by Matsuo, Horikoshi and Goriki (2006), Formation and Development of CSR Theory, Minerva Publisher, Japan, pp.355-365.

Ministry of Economic, Trade and Industry, White Paper 2003, Chapter 1.

Ministry of Environment, Environmental White Paper 2004.

Ministry of Finance (2006), "Towards expansion of environmentally friendly money flow" (Japanese), Environmental Expert committee on Environment and Finance, July.

Nakamura H. (2005), “Stakeholders' Transformation in connection with Globalization: Issues and Responses from CSR perspective” (in Japanese), Keieironshu No. 66, November.

Nitta K. (2002), “Corporate Governance Rating (CGR) -A more efficient approach to corporate monitoring”, NLI Research, Financial Research Group.

Nomura Research Institute, "A study on the possibility of effectively utilizing the senior population's financial assets into SRI" (in Japanese), a contracted 2005 project by Cabinet Office, Government of Japan, March 2006.

OECD (2001), International Science and Technology Co-Operation Towards Sustainable Development, Environmental Studies, 1 jan 2001, p. 359

Olson, N. R., Ventresca, M. J., and Stevenson, W. B. (2003), How institutions emerge: mechanisms in the origins and elaboration of emerging environmental management codes field. Working paper, October. 
PLEON (2005). Accounting for Good: the Global Stakeholder Report 2005: Pleon Kohtes Klewes GmbH / Pleon b.v.

Research Institute of Economy, Trade and Industry (RIETI), “About CSR and new money flow - discussion points and policy directions" (in Japanese), 23 July 2003.

Sakuma K. (2001), Chapter 12: Japan in Corporate Governance and Economic Performance, ed. By Gugler K., Oxford University Press, pp.139-155.

Sakuma K. (2004), “Japanese SRI Criteria vs. European SRI Criteria” (in Japanese), IPERI monthly magazine, vol. 45, Feb/March 2004, pp. 10-19, International Pension \& Economic Research Institute.

SIF-Japan, "Situation of SRI research firms in Japan" (in Japanese), Company Screening Study Group, SIF-Japan, September 2005.

Siggelkow N. (1999), "Expense Shifting: An empirical study of Agency Cost in mutual funds industry”, Management Dept., Wharton School, draft date: 4 January 1999. SiRi company. 2005. Green Social and Ethical Funds in Europe 2005: Avanzi SRI Research / SiRi Company.

Social Investment Forum Japan (2005), Situation of SRI Research Institutions in Japan (Japanese), Company screening working group, SIF-Japan, September.

Solomon, A., Solomon, J. F. and M. Suto (2004), "Can the UK Experience Provide Lessons for the Evolution of SRI in Japan?", Corporate Governance: An International Review, Vol.12, No.4, October, pp.552-566.

Sparkes R. (2002), Socially Responsible Investment: A Global Revolution, Wiley, Chichester.

Sparkes R. and C. J.Cowton (2004), “The maturing Of Socially Responsible Investment : A Review Of The Developing Link With Corporate Social Responsibility", Journal of Business Ethics 52: pp.45-57.

Study Group on Financial Institutions' environmental strategies, Environmental Strategies of Financial Institutions (in Japanese), Kinzai, 2005

Széll G. ed. (2006), Corporate Social Responsibility in the EU and Japan, Peter Lang 2006.

TBLI 2002 conference, "Screening: Cultural Differences", a workshop design and moderated by Kyoko Sakuma, Triple Bottom Line Investing (TBLI ) conference, Brussels, November 7, 2002 
Tanigawa H. (2004), "Voluntary incentive structure of Japanese companies in environmental practices (Nihon Kigyo no Jishuteki Kankyotaiou no Insentive Kozo), Research \& Review, May.

Tanimoto K., ed. (2003), Socially Responsible Investment (Japanese), Nihon Keizai Publisher 2003

Tencati A., F. Perrini, and S. Pogutz (2004), "New Tools to Foster Corporate Socially Responsible Behavior”, Journal of Business Ethics 53: pp.173-190.

Toyoda K. (2006), "Greening of finance in progress -large impact on the corporate sector" (in Japanese), Ecology Express, Trend Watch, 2 August 2006.

Yoshioka Y., A new trend in Japan's proxy voting (Nihon no Giketsukenkoshi no atarashii doko), a lecture report, 24 November 2006, Securities Analysts Association of Japan

Yano T. (2004), Corporate Governance activities of Pension Fund Association, power point presentation, available at: http://www.usajapan.org/PDF/TYano_1104.ppt\#256,1,

Watanabe S. and I. Yamamoto (1992), “Corporate governance in Japan: Ways to improve low profitability", NRI Quarterly, 1(3), 28-45.

Wokutch R.E. (1990), Corporate social responsibility Japanese style. Academy of Management Executive, 42: 56-74.

Wokutch R. and J. M. Shepard (1999), “The Maturing of Japanese Economy: Corporate Social Responsibility implication”, Business Ethics Quarterly 9 (3), pp. 527-540.

Wong D. (1991) "Relativism", chapter 39 in Singer, P., A Companion to Ethics, Blackwell, Oxford, UK. 


\section{Socially Responsible Investment in Japan: Its mechanism and drivers}

\section{Louche \& Sakuma}

\section{Tables and Annexes}

\section{Figure 1}

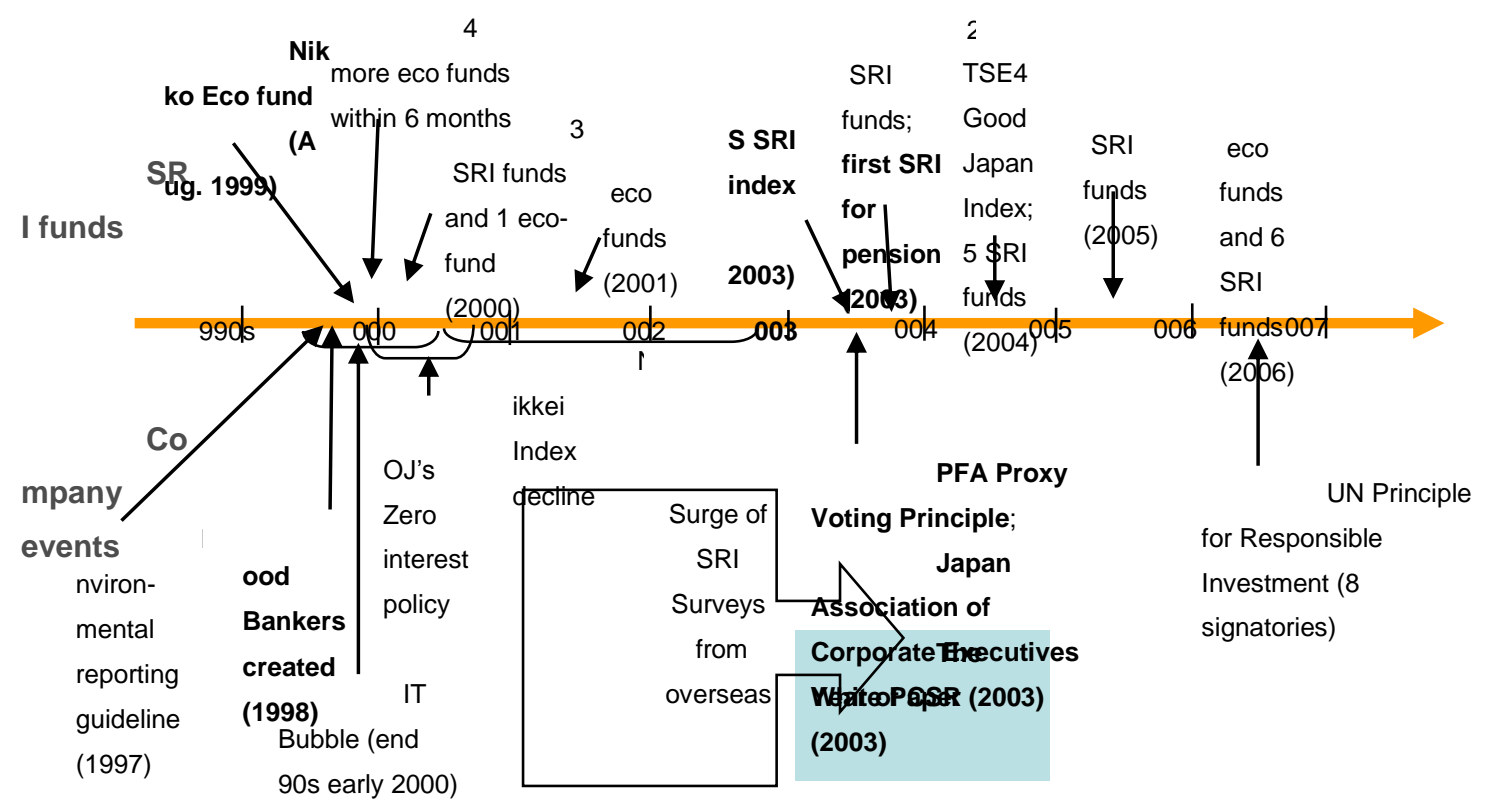

Source: elaborated by the authors 
Table 1 Relationship of SRI research companies of foreign origin with financial institutions, as of April 2006

\begin{tabular}{|c|l|l|c|}
\hline & SRI research companies & Financial institutions & \# of funds \\
\hline 1 & IRRC & AIG Asset Management & $\mathbf{3}$ \\
\hline 2 & $\begin{array}{l}\text { Innovest Strategic Value } \\
\text { Adviser }\end{array}$ & Daiwa SB Investments & $\mathbf{2}$ \\
\hline 3 & Oekom Research* & Daiwa Asset Management & $\mathbf{2}$ \\
\hline 4 & SAM & Nikko Asset Management & $\mathbf{2}$ \\
\hline 5 & $\begin{array}{l}\text { FTSE (FTSE4Good Global } \\
\text { Index) }\end{array}$ & Nomura Asset Management & 1 \\
\hline 6 & $\begin{array}{l}\text { KLD (KLD Global Climate } \\
\text { 100 Index) }\end{array}$ & $\begin{array}{l}\text { Shinko Investment Trust } \\
\text { Management }\end{array}$ & $\mathbf{1}$ \\
\hline 7 & $\begin{array}{l}\text { UBS AG (Dow Jones } \\
\text { Sustainability Wold Index) }\end{array}$ & UBS AG & 1 \\
\hline 8 & Vigeo & Asahi Life Asset Management & 1 \\
\hline
\end{tabular}

Oekom Research forms a partnership with Japan Research Institute to serve Daiwa Asset Management.

Table 2 Policy menu for placing SRI in the right track, proposed by JRI

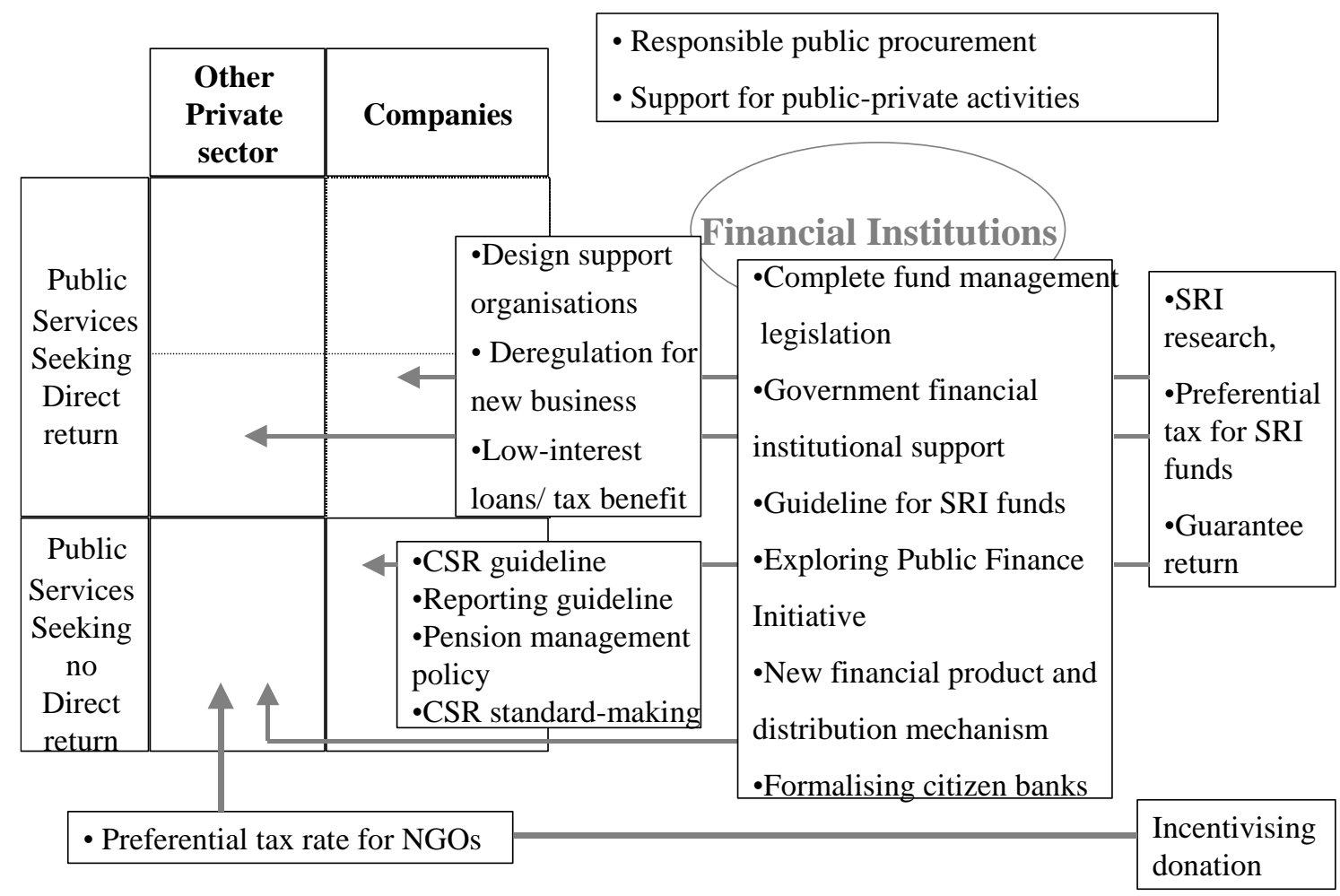

Source: Japan Research Institute 2004. The table was simplified and translated from Japanese into English by the authors.

Table 3 Comparing Japanese SRI characteristics with those of US and Europe 


\begin{tabular}{|c|c|c|c|}
\hline & Japan & US & Europe \\
\hline \begin{tabular}{|l} 
Historical roots / \\
Shared purpose
\end{tabular} & $\begin{array}{l}\text { Eco-fund launch } \\
\text { A desire to create a market mechanism to channel } \\
\text { household financial assets into SRI and Corporate sector } \\
\text { A desire to legitimate the Japanese management system } \\
\text { through new sets of vocabulary such as eco-efficiency, } \\
\text { ethics compliance and CSR in the eyes of Japanese public } \\
\text { and the world }\end{array}$ & $\mathbf{X}$ & $\mid \mathrm{X}$ \\
\hline Definitions & $\begin{array}{l}\text { Emphasis on investment methods of meeting financial } \\
\text { and social goals }\end{array}$ & $\mathbf{X}$ & $\Delta$ \\
\hline$\overline{\text { Actors }}$ & $\begin{array}{l}\text { Independent and affiliated SRI research companies } \\
\text { Companies including banks } \\
\text { Increasing government interest }\end{array}$ & $\mathrm{X}$ & $\Delta$ \\
\hline Vocabulary & \begin{tabular}{|l|} 
Screening \\
Eco-efficiency, eco-friendly \\
Compliance and integrity \\
CSR and social contribution
\end{tabular} & $\mathbf{X}$ & $\mathbf{X}(\Delta)$ \\
\hline Strategies & $\begin{array}{l}\text { Negative screens rejected } \\
\text { Positive screens stresses on scores and ranking } \\
\text { Avoidance of conflict, increasing proxy voting but no } \\
\text { ESG issues } \\
\text { Embryonic community investing }\end{array}$ & $\mathrm{X}(\Delta)$ & $\Delta$ \\
\hline
\end{tabular}

$\mathbf{X}=$ No similarities, $\boldsymbol{\Delta}=$ Some similarities, $\mathbf{X}(\boldsymbol{\Delta})=$ Some similarities but largely different 
Annex 1 SRI funds in Japan, as of 31 January 2007

\begin{tabular}{|c|c|c|c|c|c|c|}
\hline & Inception & Management firm & Fund name & Nickname & $\begin{array}{l}\text { Net Asset } \\
\text { (billion } \\
\text { JPY) }\end{array}$ & Research firm \\
\hline 1 & $1999 / 8 / 20$ & Nikko Asset Managment & Nikko Eco Fund & $\begin{array}{l}\text { Nikko Eco } \\
\text { Fund }\end{array}$ & 39.6 & Good Bankers \\
\hline 2 & $1999 / 9 / 30$ & $\begin{array}{l}\text { Sompo Japan Asset } \\
\text { Management }\end{array}$ & $\begin{array}{l}\text { Sompo Japan } \\
\text { Green Open }\end{array}$ & Buna no Mori & 18.9 & $\begin{array}{c}\text { Sompo Japan } \\
\text { Risk } \\
\text { Management }\end{array}$ \\
\hline 3 & $1999 / 10 / 29$ & $\begin{array}{c}\text { DLIBJ Asset Management } \\
\text { (DIAM) }\end{array}$ & Eco Fund & Eco Fund & 5.5 & Good Bankers \\
\hline 4 & $1999 / 10 / 29$ & $\begin{array}{l}\text { UBSGlobal Asset } \\
\text { Management }\end{array}$ & $\begin{array}{l}\text { UBS Japan Eco } \\
\text { Fund }\end{array}$ & - Dr. Eco & 3.5 & $\begin{array}{l}\text { Japan Research } \\
\text { Institute }\end{array}$ \\
\hline 5 & $2000 / 1 / 28$ & $\begin{array}{l}\text { Mitsubishi UFJ Asset } \\
\text { Management* }\end{array}$ & Eco Partners & Green Feather & 2.8 & $\begin{array}{c}\text { Mitsubishi UFJ } \\
\text { Research \& } \\
\text { Consulting }\end{array}$ \\
\hline 6 & $2000 / 9 / 28$ & $\begin{array}{l}\text { Asahi Life Asset } \\
\text { Management }\end{array}$ & $\begin{array}{c}\text { Asahi Life SRI } \\
\text { Social Action } \\
\text { Fund }\end{array}$ & $\begin{array}{l}\text { Feather of } \\
\text { Tomorrow }\end{array}$ & 5.0 & Vigeo Group*** \\
\hline 7 & $2000 / 10 / 31$ & $\begin{array}{c}\text { Sumitomo Mitsui Asset } \\
\text { Management }\end{array}$ & Eco Balance & Ocean and sky & 1.2 & $\begin{array}{l}\text { InterRisk } \\
\text { Research } \\
\text { Institute\& } \\
\text { Consulting }\end{array}$ \\
\hline 8 & $2000 / 11 / 17$ & Nikko Asset Management & $\begin{array}{c}\text { Nikko Global } \\
\text { Sustainability } \\
\text { Fund, without } \\
\text { hedge }\end{array}$ & Globe A & 1.0 & $\mathbf{S A M}$ \\
\hline 9 & $2000 / 11 / 17$ & Nikko Asset Management & $\begin{array}{c}\text { Nikko Global } \\
\text { Sustainability } \\
\text { Fund, with hedge }\end{array}$ & Globe B & 0.5 & $\mathbf{S A M}$ \\
\hline 10 & $2001 / 6 / 15$ & Daiwa SB Investments & $\begin{array}{l}\text { Global Eco } \\
\text { Growth Fund, } \\
\text { with hedge }\end{array}$ & Mrs. Green A & 1.2 & $\begin{array}{c}\text { Innovest } \\
\text { Strategic Value } \\
\text { Adviser }\end{array}$ \\
\hline 11 & $2001 / 6 / 15$ & Daiwa SB Investments & $\begin{array}{l}\text { Global Eco } \\
\text { Growth Fund, } \\
\text { without hedge }\end{array}$ & Mrs Green B & 2.4 & $\begin{array}{c}\text { Innovest } \\
\text { Strategic Value } \\
\text { Adviser }\end{array}$ \\
\hline 12 & 2003/11/7 & $\begin{array}{l}\text { UBS Global Asset } \\
\text { Management }\end{array}$ & $\begin{array}{c}\text { UBS Global Stock } \\
\mathbf{4 0}\end{array}$ & $\begin{array}{l}\text { UBS Global } \\
\text { Stock } 40\end{array}$ & 3.8 & UBS AG \\
\hline 13 & $2003 / 12 / 26$ & STB Asset Management & $\begin{array}{l}\text { STB SRI Japan } \\
\text { Open }\end{array}$ & $\begin{array}{c}\text { Good } \\
\text { Company }\end{array}$ & 56.3 & $\begin{array}{c}\text { Japan Research } \\
\text { Institute }\end{array}$ \\
\hline 14 & $2004 / 4 / 1$ & Shinkin Asset Management & Fukoku SRI Fund & - & 4.1 & $\begin{array}{c}\text { Fukoku Life } \\
\text { Asset } \\
\text { Managment, } \\
\text { Centre for Public } \\
\text { Resource } \\
\text { Development } \\
\text { (CPRD) }\end{array}$ \\
\hline 15 & $2004 / 5 / 20$ & Daiwa Asset Management & Daiwa SRI Fund & Daiwa SRI & 10.0 & IntegreX \\
\hline
\end{tabular}




\begin{tabular}{|c|c|c|c|c|c|c|}
\hline & & & & Fund & & \\
\hline 16 & $2004 / 5 / 28$ & Nomura Asset Management & $\begin{array}{l}\text { Nomura Global } \\
\text { SRI } 100\end{array}$ & $\begin{array}{c}\text { Nomura Global } \\
\text { SRI }\end{array}$ & 4.3 & FTSE \\
\hline 17 & $2004 / 7 / 30$ & $\begin{array}{l}\text { Nomura Asset } \\
\text { Management }\end{array}$ & $\begin{array}{l}\text { Morningstar SRI } \\
\text { Index Open }\end{array}$ & Tsunagari & 2.7 & $\begin{array}{c}\text { CPRD } \\
\text { (Morningstar } \\
\text { SRI Japan Index) }\end{array}$ \\
\hline 18 & $2004 / 12 / 3$ & $\begin{array}{l}\text { Mitsubishi UFJ Asset } \\
\text { Management }\end{array}$ & $\begin{array}{l}\text { Mitsubishi UFJ } \\
\text { SRI Open }\end{array}$ & $\begin{array}{l}\text { Family } \\
\text { Friendly }\end{array}$ & 4.4 & Good Bankers \\
\hline 19 & $2005 / 3 / 05$ & $\begin{array}{l}\text { Sompo Japan Asset } \\
\text { Mangement }\end{array}$ & $\begin{array}{c}\text { Sompo Japan SRI } \\
\text { Open }\end{array}$ & $\begin{array}{l}\text { Mirai no } \\
\text { Chikara }\end{array}$ & 1.6 & \begin{tabular}{|c|} 
CPRD, Sompo \\
Japan Risk \\
Management \\
(Morningstar SRI \\
Japan Index)
\end{tabular} \\
\hline 20 & $2005 / 3 / 18$ & AIG Asset Management & $\begin{array}{l}\text { AIG-Saikyo Japan } \\
\text { Stock CSR Fund }\end{array}$ & Suiren & 6.1 & I R R C \\
\hline 21 & $2005 / 3 / 18$ & AIG Asset Management & $\begin{array}{c}\text { AIG- Resona } \\
\text { Japan Stock CSR } \\
\text { Fund }\end{array}$ & Seijitu no Mori & 15.9 & I R R C \\
\hline 22 & $2005 / 4 / 28$ & AIG Asset Management & $\begin{array}{c}\text { AIG-Hirogin } \\
\text { Japan Stock CSR } \\
\text { Fund }\end{array}$ & Class G & 0.7 & I R R C \\
\hline 23 & $2005 / 8 / 12$ & $\begin{array}{l}\text { Fukoku Capital } \\
\text { Management }\end{array}$ & Japan SRI Open & Kizuna & 2.5 & $\begin{array}{l}\text { Fukoku Capital } \\
\text { Management }\end{array}$ \\
\hline 24 & 2005/11/15 & $\begin{array}{c}\text { Commerz International } \\
\text { Capital Management Japan }\end{array}$ & Asian SRI Fund & - & 0.1 & $\begin{array}{l}\text { Kingsway, } \\
\text { Moonlight } \\
\text { Capital }\end{array}$ \\
\hline 25 & 2005/12/05 & $\begin{array}{c}\text { DLIBJ Asset Management } \\
\text { (DIAM) }\end{array}$ & \begin{tabular}{|c|} 
High Rated \\
Income Open SRI \\
Fund
\end{tabular} & $\begin{array}{l}\text { Happy Clover } \\
\text { SRI }\end{array}$ & 1.7 & IntegreX \\
\hline 26 & $2006 / 2 / 06$ & $\begin{array}{c}\text { Invesco Asset Management } \\
\text { Japan }\end{array}$ & $\begin{array}{l}\text { Focus Alpha Fund } \\
\quad \text { (Plus Angle) }\end{array}$ & - & 41.7 & $\begin{array}{c}\text { Invesco Asset } \\
\text { Management } \\
\text { Japan }\end{array}$ \\
\hline 27 & $2006 / 3 / 6$ & Daiwa Asset Management & Daiwa Eco Fund & $\begin{array}{l}\text { Daiwa Eco } \\
\text { Fund }\end{array}$ & 57.1 & $\begin{array}{l}\text { Japan Research } \\
\text { Institute }\end{array}$ \\
\hline 28 & $2006 / 3 / 6$ & Daiwa Asset Management & $\begin{array}{l}\text { Six-assets balanced } \\
\text { fund, monthly } \\
\text { distributed }\end{array}$ & & 23.7 & \begin{tabular}{|c|} 
Japan Research \\
Institute, Oekom \\
Research
\end{tabular} \\
\hline 29 & $2006 / 3 / 6$ & Daiwa Asset Management & $\begin{array}{l}\text { Six-assets balanced } \\
\text { fund, accumulated }\end{array}$ & & 24.1 & $\begin{array}{c}\text { Japan Research } \\
\text { Institute, Oekom } \\
\text { Research }\end{array}$ \\
\hline 30 & $2006 / 5$ & $\begin{array}{c}\text { DLIBJ Asset Management } \\
\text { (DIAM) }\end{array}$ & $\begin{array}{c}\text { Natural } \\
\text { Environment } \\
\text { conervation Fund }\end{array}$ & Oze Kiko & 3.6 & IntegreX \\
\hline 31 & $2006 / 6$ & STB Asset Management & \begin{tabular}{|c|} 
Simitomo Trust \\
Japan Equity SRI \\
Fund
\end{tabular} & & 5.1 & $\begin{array}{l}\text { Japan Research } \\
\text { Institute }\end{array}$ \\
\hline 32 & $2006 / 6 / 30$ & $\begin{array}{l}\text { Shinko Investment Trus } \\
\text { Global Warming Prev }\end{array}$ & $\begin{array}{l}\text { t Management } \\
\text { vention Fund }\end{array}$ & Chikyu ryoku & 3.5 & $\begin{array}{c}\text { KLD } \\
\text { (KLD's Global } \\
\text { Climate } 100 \\
\text { Index) }\end{array}$ \\
\hline
\end{tabular}




\begin{tabular}{|c|c|c|c|c|c|c|}
\hline 33 & $2006 / 6 / 30$ & $\begin{array}{l}\text { Societe Generale Asset } \\
\text { Management Japan }\end{array}$ & $\begin{array}{l}\text { Love me! } \\
\text { Premium }\end{array}$ & & 2.8 & - \\
\hline 34 & $2006 / 11 / 30$ & $\begin{array}{l}\text { Chuo Mitsui Asset } \\
\text { Management }\end{array}$ & $\begin{array}{l}\text { Mitsui Trust SRI } \\
\text { Fund }\end{array}$ & SRI Plan & 0.9 & $\begin{array}{c}\text { Chuo Mitsui } \\
\text { Asset } \\
\text { Management } \\
\text { IntegreX }\end{array}$ \\
\hline \multicolumn{5}{|c|}{ TOTAL } & \multicolumn{2}{|c|}{358} \\
\hline
\end{tabular}

Source : Japan Research Institute

* UFJ Partners Asset Management was merged with Mitsubishi Asset Mangement in October 2005 to become Mitsubishi UFJ Asset Management.

** Stock at Stake was merged with Vigeo (France) in December 2005 to form jointly Vigeo group.

SRI funds for pension, as of 31 August 2006

\begin{tabular}{|c|c|c|c|c|c|}
\hline \multirow{2}{*}{$2003 / 4 / 25$} & $\begin{array}{c}\text { Tokyo Teachers' } \\
\text { Mutual Aid } \\
\text { Association }\end{array}$ & - & $\begin{array}{c}\text { For } \\
\text { pensions }\end{array}$ & - & Good Bankers \\
\hline $2003 / 7 / 31$ & $\begin{array}{c}\text { Sumitomo Trust \& } \\
\text { Banking }\end{array}$ & - & $\begin{array}{c}\text { For } \\
\text { pensions }\end{array}$ & - & $\begin{array}{c}\text { Japan Research } \\
\text { Institute }\end{array}$ \\
\hline \hline $2004 / 8 / 1$ & $\begin{array}{c}\text { Chuo Mitsui Asset } \\
\text { Management }\end{array}$ & $\begin{array}{c}\text { Chuo Mitsui } \\
\text { SRI Fund ( for } \\
\text { Institutional } \\
\text { investors) }\end{array}$ & $\begin{array}{c}\text { For 401k } \\
\text { pensions }\end{array}$ & - & IntegreX \\
\hline $2006 / 6 / 29$ & $\begin{array}{c}\text { Mitsubishi UFJ } \\
\text { Asset Management }\end{array}$ & - & $\begin{array}{c}\text { For } \\
\text { pensions }\end{array}$ & - & $\begin{array}{c}\text { Mitsubishi UFJ } \\
\text { Research \& Consulting }\end{array}$ \\
\hline
\end{tabular}

Source : SIF-Japan website 
Annex 2 Profiles of major SRI research companies of Japanese origin, as of April 2006

\begin{tabular}{|c|c|c|c|c|c|c|}
\hline & CPRD & IntegreX & JRI & $\begin{array}{c}\text { Sompo } \\
\text { Japan } \\
\text { Research } \\
\text { Institute/ } \\
\text { Sompo } \\
\text { Japan Risk } \\
\text { Management }\end{array}$ & $\begin{array}{c}\text { Mitsubishi } \\
\text { UFJ } \\
\text { Research } \\
\text { \& } \\
\text { Consulting } \\
*\end{array}$ & $\begin{array}{c}\text { InterRisk } \\
\text { Research } \\
\text { Institute \& } \\
\text { Consulting }\end{array}$ \\
\hline $\begin{array}{l}-\quad \text { Legal } \\
\text { Statute }\end{array}$ & Non-for-profit & $\begin{array}{c}\text { Stock } \\
\text { incorporated }\end{array}$ & $\begin{array}{c}\text { Stock } \\
\text { incorporated }\end{array}$ & $\begin{array}{c}\text { Stock } \\
\text { incorporated }\end{array}$ & $\begin{array}{c}\text { Stock } \\
\text { incorporated }\end{array}$ & $\begin{array}{c}\text { Stock } \\
\text { incorporated }\end{array}$ \\
\hline $\begin{array}{l}\text { Year of } \\
\text { establishment }\end{array}$ & January 2000 & June 2001 & February 1969 & - & $\begin{array}{l}\text { October } 1985 \\
*\end{array}$ & October 2001 \\
\hline $\begin{array}{l}\text { Major } \\
\text { (share) } \\
\text { owners/ } \\
\text { Affiliated } \\
\text { conglomerate }\end{array}$ & - & - & $\begin{array}{l}\text { Sumitomo } \\
\text { Mitsui } \\
\text { Financial } \\
\text { Group / } \\
\text { Sumitomo } \\
\text { Group, Mitsui } \\
\text { Group }\end{array}$ & $\begin{array}{l}\text { Sompo Japan: } \\
50 \% \\
\text { Sompo Japan } \\
\text { Group: } 50 \% \text { / } \\
\text { Former Yasuda } \\
\text { Group** }\end{array}$ & $\begin{array}{l}\text { UFJ Group } \\
\text { companies * / } \\
\text { Mitsubishi } \\
\text { Group }\end{array}$ & $\begin{array}{l}\text { Mitsui } \\
\text { Sumitomo } \\
\text { Group: 56.1\% } \\
\text { / Mitsui } \\
\text { Group, } \\
\text { Sumitomo } \\
\text { Group }\end{array}$ \\
\hline $\begin{array}{l}\text { \% of SRI in } \\
\text { total sales }\end{array}$ & $\begin{array}{l}2 / 3 \text { (monetary } \\
\text { value) }\end{array}$ & $30 \%$ & $>0.05 \%$ & $1 \%$ & $>1 \% *$ & $1.5 \%$ \\
\hline $\begin{array}{l}\text { Number of } \\
\text { companies } \\
\text { evaluated }\end{array}$ & $300-400$ & $851(2004)$ & $270(2004)$ & $792(2004)$ & 300 & 150 \\
\hline \# of analysts & $\begin{array}{l}4 \text { full-time } \\
2 \text { part-time }\end{array}$ & 3 full-time & $\begin{array}{l}5 \text { part-time } \\
\text { /double- } \\
\text { tasked }\end{array}$ & 6 full-time & $\begin{array}{l}4 \text { full-time } \\
3 \text { part-time }\end{array}$ & 4 full-time \\
\hline $\begin{array}{l}\text { Source of } \\
\text { research info }\end{array}$ & $\begin{array}{l}\text { Questionnaire, } \\
\text { CSR reports, } \\
\text { other } \\
\text { disclosed } \\
\text { company info }\end{array}$ & $\begin{array}{l}\text { Questionnaire, } \\
\text { CSR reports, } \\
\text { other disclosed } \\
\text { company info }\end{array}$ & $\begin{array}{l}\text { Questionnaire, } \\
\text { CSR reports, } \\
\text { other } \\
\text { disclosed } \\
\text { company info }\end{array}$ & $\begin{array}{l}\text { Questionnaire, } \\
\text { CSR reports, } \\
\text { other disclosed } \\
\text { company info }\end{array}$ & $\begin{array}{l}\text { Questionnaire, } \\
\text { CSR reports, } \\
\text { other } \\
\text { disclosed } \\
\text { company info }\end{array}$ & $\begin{array}{l}\text { Questionnaire, } \\
\text { CSR reports, } \\
\text { other } \\
\text { disclosed } \\
\text { company info }\end{array}$ \\
\hline $\begin{array}{l}\text { Weight of } \\
\text { rating }\end{array}$ & $\begin{array}{l}\text { Priority is } \\
\text { basically } \\
\text { management } \\
\text { systems and } \\
\text { vision. } \\
\text { Performance is } \\
\text { only on social } \\
\text { issues. }\end{array}$ & $\begin{array}{l}\text { Top commitment: } \\
35 \% \text {, } \\
\text { Transparency: } 30 \% \\
\text { Compliance } \\
\text { management: } 25 \% \\
\text { Own } \\
\text { initiatives: } 10 \%\end{array}$ & $\begin{array}{l}\text { Higher } \\
\text { weighting is } \\
\text { given to items } \\
\text { with larger } \\
\text { differences } \\
\text { among } \\
\text { companies. }\end{array}$ & $\begin{array}{l}\text { More weight is } \\
\text { being given to } \\
\text { performance } \\
\text { compared to } \\
\text { before. }\end{array}$ & $\begin{array}{l}\text { Priority is in the } \\
\text { following } \\
\text { order: Vision, } \\
\text { management } \\
\text { system and } \\
\text { performance. }\end{array}$ & $\begin{array}{l}\text { Priority is in the } \\
\text { following } \\
\text { order: } \\
\text { Performance, } \\
\text { management } \\
\text { system and } \\
\text { vision. }\end{array}$ \\
\hline
\end{tabular}

Source: SIF-Japan survey, September 2005

Note: SIF-Japan focused its survey on the research provider of Japan-based retail SRI funds. Good Bankers did not participate in the survey and Vigeo Group (then Stock at Stake) was not able to share date due to propriety nature of the research.

*The data applies uniquely to UFJ Institute, which is pre-merger entity of Mitsubishi UFJ Research \& Consulting.

** Yasuda Fire \& Marine and Nissan Fire \& Maine merged to create Sompo Japan in 2002. 
Annex 3 - SRI definition used by several actors in Japan

\begin{tabular}{|c|c|c|c|}
\hline Actors & \multicolumn{2}{|l|}{ Definition } & Source \\
\hline \multirow[t]{2}{*}{$\begin{array}{l}\text { Corporate } \\
\text { sector }\end{array}$} & $\begin{array}{l}\text { Keizai Doyukai } \\
\text { (Japan Association of } \\
\text { Corporate } \\
\text { Executives) }\end{array}$ & SRI is used without definition or explanation. & $\begin{array}{l}\text { White Paper } \\
\text { on CSR }\end{array}$ \\
\hline & SIF-Japan & $\begin{array}{l}\text { An investment method by which companies are evaluated } \\
\text { and selected according to their environmental response and } \\
\text { social activities in addition to their financial outlook. .... } \\
\text { Besides, bond investment, project finance and community } \\
\text { investment are included as far as social responsibility criteria } \\
\text { are employed. ....... In the equity investment, engagement by } \\
\text { shareholders is also considered as broad SRI. .....It is about } \\
\text { the money flow that considers social aspects and the financing } \\
\text { activities that will make such a money flow". }\end{array}$ & - Website \\
\hline \multirow[t]{5}{*}{$\begin{array}{l}\text { Financial } \\
\text { sector }\end{array}$} & $\begin{array}{l}\text { STB Asset } \\
\text { Management }\end{array}$ & $\begin{array}{l}\text { An investment activity which places importance on social } \\
\text { profiles of companies in addition to the companies' profit } \\
\text { growth and the health of balance sheet. }\end{array}$ & Website \\
\hline & $\begin{array}{l}\text { Nikko Asset } \\
\text { Management }\end{array}$ & $\begin{array}{l}\text { To select and invest in companies from the perspectives of } \\
\text { sustainability. }\end{array}$ & Website \\
\hline & $\begin{array}{l}\text { Daiwa Asset } \\
\text { Management }\end{array}$ & $\begin{array}{l}\text { An investment activity which takes into account corporate } \\
\text { social responsibility. }\end{array}$ & Website \\
\hline & $\begin{array}{l}\text { Sompo Japan Asset } \\
\text { Management }\end{array}$ & $\begin{array}{l}\text { An investment method to select companies with CSR } \\
\text { management (environment and social rules ) among excellent } \\
\text { financial performance. }\end{array}$ & website \\
\hline & $\begin{array}{l}\text { Mitsubishi UFJ Asset } \\
\text { Mangement }\end{array}$ & $\begin{array}{l}\text { An asset management method by which companies are } \\
\text { evaluated not only from the financial perspective, but also } \\
\text { from their social existence. }\end{array}$ & Website \\
\hline \multirow{5}{*}{$\begin{array}{l}\text { SRI } \\
\text { research }\end{array}$} & Good Bankers & No definition given & Website \\
\hline & IntegreX & $\begin{array}{l}\text { As investment criteria in asset management, to select the } \\
\text { investment objects based not only on financial aspects but } \\
\text { also on social and ethical aspects. This means that an investor } \\
\text { approves the social and ethical values of the companies and } \\
\text { supports them through the financial market. As a result, the } \\
\text { companies and the investors are able to share the values. }\end{array}$ & Website \\
\hline & Morningstar Japan & $\begin{array}{l}\text { An investment method which aims to obtain stable return, by } \\
\text { evaluating and selecting companies from social, ethical and } \\
\text { environmental aspects such as legal compliance, employment, } \\
\text { human rights, consumer relations, community contribution, in } \\
\text { addition to the conventional financial analysis and investment } \\
\text { criteria. }\end{array}$ & Website \\
\hline & $\begin{array}{l}\text { Centre for Public } \\
\text { Resource } \\
\text { Development }\end{array}$ & $\begin{array}{l}\text { SRI is an idea/way of integrating social and environmental } \\
\text { evaluation into the traditional financial evaluation when } \\
\text { selecting stocks. }\end{array}$ & Website \\
\hline & $\begin{array}{l}\text { Japan Research } \\
\text { Institute's } 2004 \\
\text { report }\end{array}$ & $\begin{array}{l}\text { Investing and lending activities of finance providers, who } \\
\text { evaluate the companies that meet both the economic } \\
\text { performance and the social responsibility and also the } \\
\text { activities/initiatives of NGOs and local public bodies that aim } \\
\text { to solve the societal problems. }\end{array}$ & $\begin{array}{l}\text { JRI March } \\
2004 \text { report }\end{array}$ \\
\hline
\end{tabular}

Source: The information was taken from the website between December 2006 and February 2007. All the definition was translated from Japanese to English by the authors. The financial sector actors are selected according to the size of SRI funds. 
Annex 4 - Overview of the main differences Japan vs US/Europe

\begin{tabular}{|c|c|c|c|}
\hline & Japan & US & Europe \\
\hline $\begin{array}{l}\text { Historic } \\
\text { roots } \\
\text { Motivation }\end{array}$ & $\begin{array}{l}\text { Eco-fund launch } \\
\text { A desire to create a market } \\
\text { mechanism to channel household } \\
\text { money to SRI } \\
\text { A desire to demonstrate Japanese } \\
\text { management legitimacy }\end{array}$ & \multicolumn{2}{|c|}{$\begin{array}{l}\text { Religious background } \\
\text { A desire to redefine the relationship between } \\
\text { corporations and society }\end{array}$} \\
\hline Definition & $\begin{array}{l}\text { Emphasis on financial objectives } \\
\text { and investment impacts }\end{array}$ & $\begin{array}{l}\text { Emphasis on personal } \\
\text { values and social } \\
\text { purpose }\end{array}$ & $\begin{array}{l}\text { Emphasis on financial } \\
\text { objectives and } \\
\text { investment impacts }\end{array}$ \\
\hline Actors & $\begin{array}{l}\text { No active retail and institutional } \\
\text { investors } \\
\text { Independent SRI firms and } \\
\text { financial-group-affiliated think tanks } \\
\text { Companies } \\
\text { Increasing government interest }\end{array}$ & $\begin{array}{l}\text { Retail investors } \\
\text { SRI firms } \\
\text { independent of the } \\
\text { mainstream financial } \\
\text { community } \\
\text { Little government } \\
\text { involvement }\end{array}$ & $\begin{array}{l}\text { Institutional investors } \\
\text { Mainstream financial } \\
\text { community promoting } \\
\text { SRI activities } \\
\text { Substantive government } \\
\text { involvement }\end{array}$ \\
\hline Vocabulary & $\begin{array}{l}\text { Screening } \\
\text { Eco efficiency and eco-friendly } \\
\text { Ethics compliance and integrity } \\
\text { CSR } \\
\text { Social contribution }\end{array}$ & $\begin{array}{l}\text { Social responsibility } \\
\text { Fairness and justice } \\
\text { Access to capital } \\
\text { Wealth creation } \\
\text { Exclusionary and } \\
\text { qualitative screens } \\
\text { Shareholder activism }\end{array}$ & $\begin{array}{l}\text { Sustainability } \\
\text { Eco-efficiency and } \\
\text { business case } \\
\text { Triple Bottom Line } \\
\text { investing } \\
\text { Best of class investing } \\
\text { Negative and positive } \\
\text { screens } \\
\text { Engagement }\end{array}$ \\
\hline $\begin{array}{l}\text { SRI } \\
\text { strategy }\end{array}$ & $\begin{array}{l}\text { Negative screens rejected } \\
\text { Avoidance of companies with } \\
\text { negative press coverage } \\
\text { Non-conflictual and casting votes in } \\
\text { the shareholders' meeting }\end{array}$ & $\begin{array}{l}\text { Exclusionary screen } \\
\text { crucially important } \\
\text { Positive screens } \\
\text { stress judgement } \\
\text { Activism often public } \\
\text { and through proxy } \\
\text { resolutions }\end{array}$ & $\begin{array}{l}\text { Negative screens not } \\
\text { emphasized } \\
\text { Positive screens stressed } \\
\text { quantitative } \\
\text { measurements } \\
\text { Engagement often } \\
\text { through behind-the- } \\
\text { scenes dialogue }\end{array}$ \\
\hline
\end{tabular}

